\title{
Interactions between Climate and Nutrient Cycles on Forest Response to Global Change: The Role of Mixed Forests
}

\author{
Ester González de Andrés \\ Departamento de Ciencias, Universidad Pública de Navarra, Campus de Arrosadía, Pamplona, \\ 31006 Navarra, Spain; ester.gonzalez@unavarra.es; Tel.: +34-948-169-156
}

Received: 24 June 2019; Accepted: 22 July 2019; Published: 24 July 2019

\begin{abstract}
Forest ecosystems are undergoing unprecedented changes in environmental conditions due to global change impacts. Modification of global biogeochemical cycles of carbon and nitrogen, and the subsequent climate change are affecting forest functions at different scales, from physiology and growth of individual trees to cycling of nutrients. This review summarizes the present knowledge regarding the impact of global change on forest functioning not only with respect to climate change, which is the focus of most studies, but also the influence of altered nitrogen cycle and the interactions among them. The carbon dioxide $\left(\mathrm{CO}_{2}\right)$ fertilization effect on tree growth is expected to be constrained by nutrient imbalances resulting from high $\mathrm{N}$ deposition rates and the counteractive effect of increasing water deficit, which interact in a complex way. At the community level, responses to global change are modified by species interactions that may lead to competition for resources and/or relaxation due to facilitation and resource partitioning processes. Thus, some species mixtures can be more resistant to drought than their respective pure forests, albeit it depends on environmental conditions and species' functional traits. Climate change and nitrogen deposition have additional impacts on litterfall dynamics, and subsequent decomposition and nutrient mineralization processes. Elemental ratios (i.e., stoichiometry) are associated with important ecosystem traits, including trees' adaptability to stress or decomposition rates. As stoichiometry of different ecosystem components are also influenced by global change, nutrient cycling in forests will be altered too. Therefore, a re-assessment of traditional forest management is needed in order to cope with global change. Proposed silvicultural systems emphasize the key role of diversity to assure multiple ecosystem services, and special attention has been paid to mixed-species forests. Finally, a summary of the patterns and underlying mechanisms governing the relationships between diversity and different ecosystems functions, such as productivity and stability, is provided.
\end{abstract}

Keywords: atmospheric carbon dioxide $\left(\mathrm{CO}_{2}\right)$ concentration; drought; $\mathrm{N}$ deposition; species interactions; ecosystem stoichiometry; adaptive management; diversity-functioning relationships

\section{Introduction}

Worldwide, forests cover 4.03 billion hectares, $\mathrm{Ca}$. 30\% of Earth's total land area. They account for $75 \%$ of terrestrial gross primary production, $80 \%$ of Earth's total plant biomass, and contain more carbon in biomass and soils than is stored in the atmosphere [1]. Globally, they support over half of all described species and provide a range of valuable goods and ecosystem services, including food, fiber, timber, medicine, clean water, aesthetic and spiritual values [2]. Forests play a particularly significant role in climate regulation, owing to their low albedo and high rates of evapotranspiration [3,4]. Forest ecosystems are associated with the regulation of $57 \%$ of total water runoff and about 4.6 billion people depend for all or some of their water on supplies from forests [5]. 
Human appropriation of land and water for agriculture and other purposes; emission of extraneous compounds to the atmosphere and water, extraction of food, fuel, and fiber from natural ecosystems; and transport of species around the globe, have pervasively influenced Earth's climate, hydrology, biogeochemistry, land cover, and species diversity [6,7]. The Earth and its ecosystems are undergoing rapid global change, driven by natural and human-induced factors, that is expected to influence plant species' dominance and distribution, primary productivity, and nutrient cycles worldwide $[5,8]$. Demographic, economic, socio-political, cultural, scientific, and technological factors (i.e., indirect drivers) cause physical and biological changes (i.e., direct drivers) in ecosystems. Global change involves the simultaneous and rapid alteration of several key environmental parameters that control the dynamics of forests $[9,10]$. Hence, forest ecosystems are currently facing unprecedented shifts in environmental conditions, with implications for biodiversity patterns, ecosystem functions, and services $[4,11]$.

In this study, I first provide a brief description of the alteration of carbon (C) and nitrogen $(\mathrm{N})$ cycles and the subsequent climate change that may affect forests. Second, a review of possible responses of forests to global change impacts is presented at three different scales: (i) individual tree level physiology and growth, (ii) influence of species' interactions at the community level, and (iii) nutrient cycling and stoichiometry of forests at the ecosystem level. Finally, bases for forest management in the face of global change are succinctly discussed with the focus on mixed-species forests as an adaptation strategy. In order to provide a comprehensive insight into the current state-of-the-art, an exhaustive review of existing bibliography has been conducted.

\section{Alteration of Biogeochemical Cycles and Global Climate}

The post-industrial planet has experienced a striking increase in atmospheric concentrations of the greenhouse gases carbon dioxide $\left(\mathrm{CO}_{2}\right)$, methane $\left(\mathrm{CH}_{4}\right)$, and nitrous oxide $\left(\mathrm{N}_{2} \mathrm{O}\right)$, which have substantially exceeded the highest concentrations recorded in ice cores during the past 800,000 years. In 2014, atmospheric $\mathrm{CO}_{2}$ concentration ( $\mathrm{Ca}$ ) surpassed the threshold of 400 p.p.m. and this concentration may double in the 21st century relative to concentrations recorded prior to 1850 [12]. From 1750 to 2011, anthropogenic $\mathrm{CO}_{2}$ emissions released $555 \mathrm{Gt} \mathrm{CO}_{2}$ year $^{-1}$ (GtC) and are mainly attributed to fossil fuel combustion, cement production, and land use changes such as deforestation (Figure 1A) [13]. The steep rise in $\mathrm{Ca}$ and other greenhouse gases has been associated with ocean acidification and alteration of global climatic regimes. Mean global surface temperature has raisen on average by $0.85^{\circ} \mathrm{C}$ since the late 19th century, and this warming has been particularly marked since the 1970s (Figure 1B). Furthermore, air temperatures are projected to continue increasing globally, possibly by as much as $4.8^{\circ} \mathrm{C}$ by 2100 [12].

On the other hand, modification of the global hydrological cycle has been spatially heterogeneous, with precipitation increases in mid- and high-latitude land areas of the Northern hemisphere, while for other latitudinal zones precipitation trends have been less consistent [14]. Occurrence of extreme weather and climatic events has also increased since the middle of the 20th century, such as increases in either the frequency or intensity of heavy precipitation in North America and Europe, or drought events in the Mediterranean and West Africa [12,15]. Precipitation patterns are predicted to undergo further changes, with most arid and semiarid areas becoming drier and with an increase in heavy precipitation events, leading to an increased incidence in floods and droughts [12]. Furthermore, there is evidence that main large-scale atmospheric-oceanic circulation patterns, such as the North Atlantic Oscillation (NAO), which affects the severity of winter temperatures and precipitation in Europe and eastern North America, and the El Niño - Southern Oscillation (ENSO), which has large regional effects around the world, are behaving in unusual ways that appear to be linked to global warming [16].

Despite the growing concern for climate change impacts, global change is not restricted to climate since other drivers exert dramatic pressures on the ecosystems [8]. Burning fossil fuels, the advent of the Haber-Bosch process to create reactive $\mathrm{N}$ from atmospheric $\mathrm{N}_{2}$ as fertilizer inputs, human-caused 
biological fixation of atmospheric $\mathrm{N}_{2}$ by cultivated leguminous crops and rice, as well as an increase in mass transportation and livestock numbers have drastically altered the global N cycle [6,17-19]. The consequent formation of nitrous oxides has resulted in a widespread increase in the $\mathrm{N}$ deposition, which has tripled since 1860 (Figure 1C) [6,20,21]. N deposition mostly impacts northern ecosystems, especially around densely populated areas, but will likely extend to the tropics during the 21st century [20,22,23]. Annual anthropogenic N deposition amounts to roughly 165-259 $\mathrm{Mton} \mathrm{N}$ year $^{-1}$, and only ca. $22 \%$ of these inputs ends up accumulating in the soil and biomass [24]. Although in some regions, such as Europe and North America, N deposition levels are declining since the last decades [21] due to emission abatement policies and economic transformation [25]. $\mathrm{N}$ deposition from agricultural activities remain high and a large percentage of ecosystems are at risk of eutrophication [26]. Long-term $\mathrm{N}$ loading has been shown to alter soil nutrient cycling and promote soil acidification and leaching of nitrate and soil cations $[27,28]$, and it is one of the greatest threats to global plant diversity $[6,29]$.
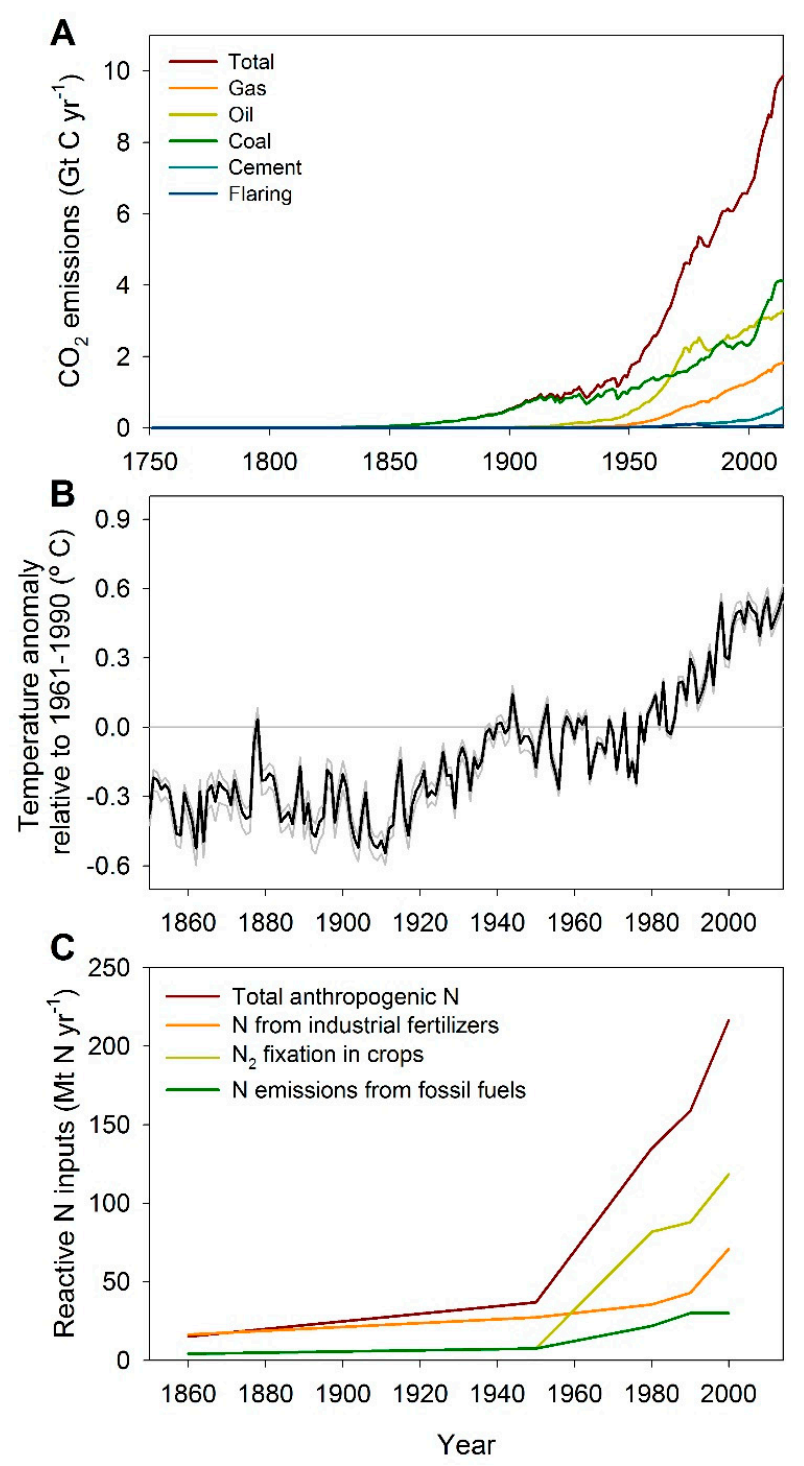

Figure 1. (A) Fossil fuel and cement $\mathrm{CO}_{2}$ emissions by category, estimated by the Carbon Dioxide Information Analysis Center (CDIAC) based on UN energy statistics for fossil fuel combustion and US Geological Survey for cement production [30]. (B) Global average land-sea temperature anomaly relative to the 1961-1990 average temperature: grey lines represent upper and lower 95\% confidence intervals [31]. (C) Anthropogenic reactive nitrogen inputs to the biosphere by sources [17]. 
The complex interactions among altered biogeochemical cycles, climate change, land-use changes, introduced species, and further global change drivers make it extremely difficult to forecast ecosystem changes [32], which can have both short-term or ecological and long-term or evolutionary consequences [13]. In addition, the interactions among different impacts of global change frequently generate non-additive effects on ecosystems that cannot be predicted based on single-factor studies [8,33-36]. The following section summarize the combined effect of $\mathrm{C}$ and $\mathrm{N}$ altered cycles and the consequent climate change at three levels of forest ecosystems' organization: (i) tree physiology and growth, (ii) tree-to-tree interactions, and (iii) nutrient cycles.

\section{Impacts of Global Change on Forest Ecosystems}

\subsection{Tree Physiology and Growth}

One of the main concerns is how elevated $C a$ could affect forests productivity [37]. Despite the significant rise in $\mathrm{Ca}$, current levels do not suffice to saturate photosynthesis of unstressed $\mathrm{C} 3$ tree species [38,39]. Thus, increasing $\mathrm{Ca}$ will enhance the rate of carboxylation by the photosynthetic enzyme system and reduce photorespiration $[40,41]$. Increased $\mathrm{Ca}$ might also induce a partial closure of stomata, reducing water loss by transpiration, which results in an increase in the ratio of the carbon gain to water loss, i.e., water-use efficiency (WUE) [42-44]. In addition to direct leaf biochemical effects, indirect effects have been associated to rising $\mathrm{Ca}$, such as soil moisture savings due to reduced transpiration and changes in leaf area index [45]. The combined direct and indirect effects have been commonly referred as $\mathrm{CO}_{2}$ fertilization [46].

As a consequence of such fertilization effect, an enhancement of forest productivity is expected to occur [37]. Many tree-ring studies have reported either positive [47-51], or neutral to negative [52-58] growth responses to rising $\mathrm{Ca}$. Such inconsistent results reveals the existence of other factors that may influence tree growth $[37,40,59]$. There are also concerns that $\mathrm{CO}_{2}$ fertilization detected by tree-rings is an artifact of sampling bias [60].

On one hand, long-term elevated $\mathrm{Ca}$ exposure studies suggest that a reduction of photosynthetic capacity occurs over time [44,61]. Down-regulation has been associated with several processes such as a reduction in the capacity of dark reactions to process $\mathrm{CO}_{2}$ due to the decrease in leaf $\mathrm{N}$ concentrations [62], or long-term anatomical and physiological adaptations for adjusting intercellular $\mathrm{CO}_{2}$ concentration to rising $\mathrm{Ca}$, including changes in stomatal density [63]. On the other hand, when trees are exposed to increased $\mathrm{Ca}$, different co-occurring circumstances not related to $\mathrm{CO}_{2}$ fertilization, such as temperature increase, drought events, or nutrient limitation, may become more important, thus modifying trees' ability to increase growth rates $[9,64,65]$.

Nutrient limitation is hypothesized as a primary cause for the reduced or lacking $\mathrm{CO}_{2}$ fertilization effect [66-68]. $\mathrm{N}$ constrains net primary production in terrestrial ecosystems. As a critical component of many important structural, genetic, and metabolic compounds in plant cells, $\mathrm{N}$ is required in relatively large quantities in connection to all growth processes [44]. Trees growing under rising $\mathrm{Ca}$ will increase the $\mathrm{N}$ demand and enhance $\mathrm{N}$ sequestration in long-lived biomass and soils, thus $\mathrm{N}$ availability will progressively decline [69]. As a consequence, long-term tree growth responses to increased $\mathrm{Ca}$ could be reduced due to $\mathrm{N}$ limitations, as predicted by the progressive $\mathrm{N}$ limitation hypothesis [66]. This hypothesis would be particularly important in temperate and boreal forests, whose young soils have been traditionally considered as $\mathrm{N}$-limited and where $\mathrm{N}$ mineralization can be limited by low temperatures $[70,71]$.

The synergistic effect of increased $\mathrm{Ca}$ and rising $\mathrm{N}$ deposition is expected to stimulate forest productivity [72], as has been reported in some boreal and temperate forests [73-79]. Such tree growth enhancement may be related to increases in foliar $\mathrm{N}$ content that can lead to improved photosynthetic capacity by enhanced photosynthetic enzyme activity and/or increasing leaf area $[80,81]$. Nevertheless, changes in $\mathrm{C}$ allocation from fine roots and mycorrhizal fungi to woody components rather than increasing photosynthesis have been also detected in long-term N-fertilization experiments [82]. 
Indeed, higher aboveground investments and increased shoot-root ratios have been found with increasing nutrient availability [83]. However, other studies report decreasing or negative growth responses, particularly at high $\mathrm{N}$ deposition rates $[53,79,84-86]$, and even tree mortality under $\mathrm{N}$ saturation $[77,87]$. Such findings fit the N-saturation hypothesis $[85,88]$, according to which tree growth responds unimodally to increasing $\mathrm{N}$ deposition (Figure 2A). Low to moderate levels of $\mathrm{N}$ deposition will relieve trees from growth limitation due to originally widespread $\mathrm{N}$ shortage. A critical threshold of $\mathrm{N}$ saturation is reached when $\mathrm{N}$ availability exceeds microbial and plant demands. Prolonged high $\mathrm{N}$ availability eventually leads to substantial leaching, growth decreases, and damage to forests due to nutrient imbalances, soil acidification, and increased susceptibility to biotic and abiotic stresses $[9,17,84]$. Thus, it is expected that high polluted forests may benefit from current declining trends in $\mathrm{N}$ deposition $[19,89]$.

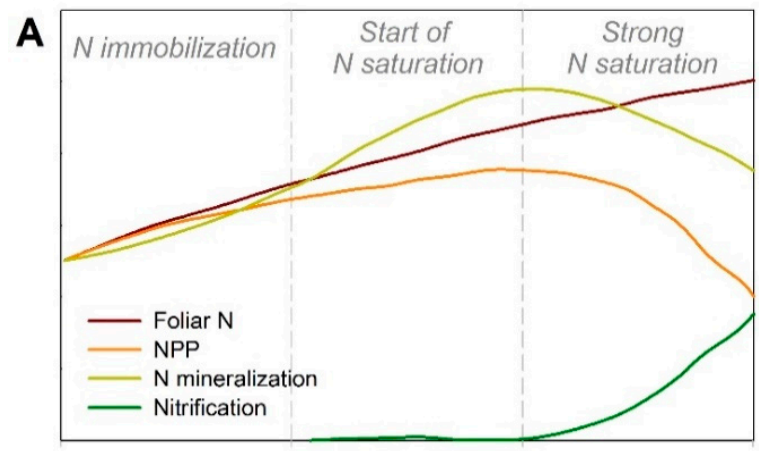

Cumulative $\mathrm{N}$ input

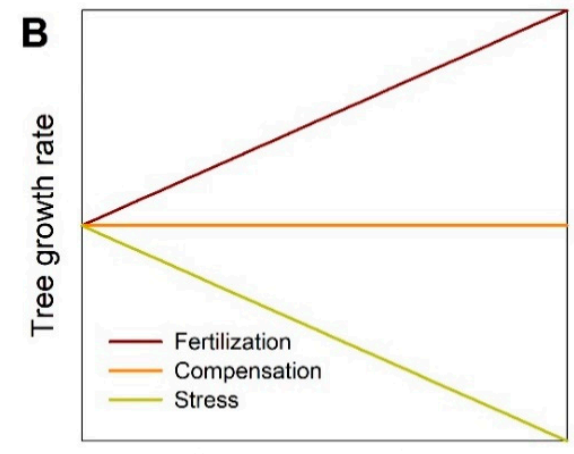

Water-use efficiency

Figure 2. (A) Hypothetical responses of temperate forest ecosystems to long-term external $\mathrm{N}$ inputs in terms of foliar $\mathrm{N}$, net primary production (NPP), and $\mathrm{N}$ biogeochemical processes, including $\mathrm{N}$ mineralization, nitrification, and leaching losses (adapted from [88]). (B) Expected relationships between water-use efficiency (WUE) and tree growth (adapted from [56]). When increased WUE, resulting from rising atmospheric $\mathrm{CO}_{2}$ concentrations and/or water stress can override the physiological response to stress, $\mathrm{a} \mathrm{CO}_{2}$ fertilization effect on growth is expected (Fertilization). Conversely, if water, nutritional, or other type of stress is too strong, a negative growth-WUE would occur (Stress). No change is expected when $\mathrm{CO}_{2}$ stimulation compensates for stress (Compensation).

Whereas boreal and temperate forests have been globally considered N-limited, older and highly leached tropical soils are usually phosphorus (P) depleted [70], as well as in Mediterranean areas due to the interaction with water availability [90]. Increases in P limitation and deterioration of tree P nutrition in temperate forests have been already observed [17,91-93], and may arise from nutrient imbalances related to high $\mathrm{N}$ deposition rates $[17,19,88]$. $\mathrm{N}$ surplus can induce $\mathrm{P}$ limitation through enhancement of nutrient requirements to maintain growth under $\mathrm{N}$ fertilization [24], and reduced investment in fine root biomass and mycorrhizal interactions [92,94]. This deterioration in the P nutritional status is expected to limit tree response to rising $\mathrm{C} a$ and $\mathrm{N}$ deposition $[79,95]$.

The fertilization effects of $\mathrm{CO}_{2}$ and $\mathrm{N}$ on tree growth are also modulated by climatic conditions. Observed and projected increasing temperatures coupled with rising $\mathrm{Ca}$ are expected to enhance tree growth directly through the influence on xylogenesis activity [96], or lengthening of the growing season [97]. However, despite the concurrent effects of temperature and WUE improvement, resulting from rising $\mathrm{Ca}$ and reduced water availability [42,44,98], no clear evidence of positive tree growth response has been found in the last decades [53,56,99]. Instead, global growth response patterns in relation to temporal changes in WUE have been proposed to be dependent on water stress following a latitudinal gradient [56]. In cold regions, where water availability is usually not a limiting factor, the synergistic effect of warming and elevated $\mathrm{Ca}$ stimulates tree growth, as it has been observed in high altitude and high latitude regions $[59,64,100]$. The growth-WUE relationship becomes progressively more negative in Mediterranean, arid, subtropical, and tropical forests [52,54,58,99,101,102]. In warm 
regions, higher temperatures often lead to increased leaf-to-air vapor pressure deficit, with the subsequent reduction of stomatal conductance $[98,103]$. Stomatal closure prolongs survival on limited water supply by reducing transpiration and the risk of hydraulic failure, but this situation also reduces photosynthesis and growth [104-106]. If water deficit is long and/or intense enough, drought-induced mortality may occur by means of hydraulic failure or hydraulically mediated $C$ starvation, and subsequent predisposition to attack from biotic agents $[105,107]$.

Hence, $\mathrm{CO}_{2}$ fertilizer effect, and the subsequent beneficial influence of enhanced WUE, can be cancelled out by physiological stress (Figure 2B), including water deficit or nutritional interactions. Water availability has been found to modify tree growth responses to $\mathrm{N}$ deposition in boreal and temperate conifers and deciduous species $[82,108,109]$. This fact is supported by modeling and forest inventory-based studies, which stated that sensitivity of forest productivity to $\mathrm{N}$ input depends on climate variability and P nutrition $[95,110]$. High nutrient availability pre-disposes trees to experience greater water stress as they likely intensify water demand and reduce uptake capacity $[35,82,108]$, and increases vulnerability to hydraulic failure under intensive water stress [111]. Meanwhile, trees growing under low nutrient availability will be more strongly affected by decreased nutrient availability and uptake during a drought event [112], thus increasing probabilities of $C$ starvation under long-term water stress.

Furthermore, both situations may be modified by biotic agents. In fact, alterations in temperature and precipitation regimes have an impact on herbivore and pathogen survival, reproduction, dispersal, and distribution [32]. Wide areas of forests worldwide have been reported to have been affected by insect pests [113], which may cause regional mortality events [114]. Elevated nutrient availability results in low C:N ratios, thus increasing palatability to biotic agents [115]. On the contrary, low nutrient availability situations can lead to reduced production of N-based defense compounds [111], whose mobility may be limited by water stress [115].

Multiple interactions among $\mathrm{Ca}, \mathrm{N}$ deposition, and climate over the physiological and growth responses of trees may occur. Interactions among different drivers introduce further complexity, because their effects can be synergistic or antagonistic, and not simply additive [36,116]. Understanding the dependencies among different impacts of global change is highly relevant in order to develop proper models that predict structure and functioning alterations of forest ecosystems in the face of global change [17,92]. Growth responses to environmental shifts are difficult to infer from tree responses to single factors [117]. However, observational or experimental multifactor studies in forests are still scarce (refer to $[35,95,108,109,118]$ ).

In addition, the nature of the combined effect of $\mathrm{N}$ deposition and drought on tree response to $\mathrm{CO}_{2}$ fertilization is not only dependent on the physiological response of individual trees but is greatly modified by competing neighbors and stand structure $[34,108,119,120]$. The importance of species' interactions on the influence of global change is addressed in the following section.

\subsection{Species Interactions}

Tree-to-tree interactions can have greater influence on forest functioning than climate [102,121-123]. In forests, trees compete for light, water, and nutrients. When different tree species are present in a stand, forest performance can be modified from that expected from the performance of single-species forests by biodiversity effects. It has been found that trees exposed to intraspecific competition grew worse than trees in interspecific neighborhoods [102,122,124]. Two main processes contribute to positive biodiversity effects: facilitation (positive effect exerted by one species on the functioning of cohabiting species [125]), and resource partitioning (differences in functional traits that reduce competition for resources [126]). Both processes refer to biological mechanisms that modify the environment and the degree of stress experienced by trees [127], and generally are difficult to differentiate [128], so they are collectively named as relaxation (sensu [129]). Light, water, nutrient, and biotic related mechanisms underlie biodiversity effects (Figure 3). A thorough list of such mechanisms can be found in [128] and [129]. 
Changes in environmental conditions may lead to different situations regarding species interactions [129]. First, greater complementarity (variation of functional traits that enables a permanent association of species that enhances collective performance [130]) can develop as one or more species become less dominant. Second, changes in competitive balance among species can lead to a shift in species dominance and composition from an initial pool of species by means of selection effects $[127,130]$. Although tree biodiversity experiments support that positive mixing effects mostly result from selection effects [131,132], there is also empirical evidence that complementarities occur in tree mixtures that enhance productivity $[133,134]$. Finally, one or more species could migrate to a new area and establish novel interactions with species already established there.

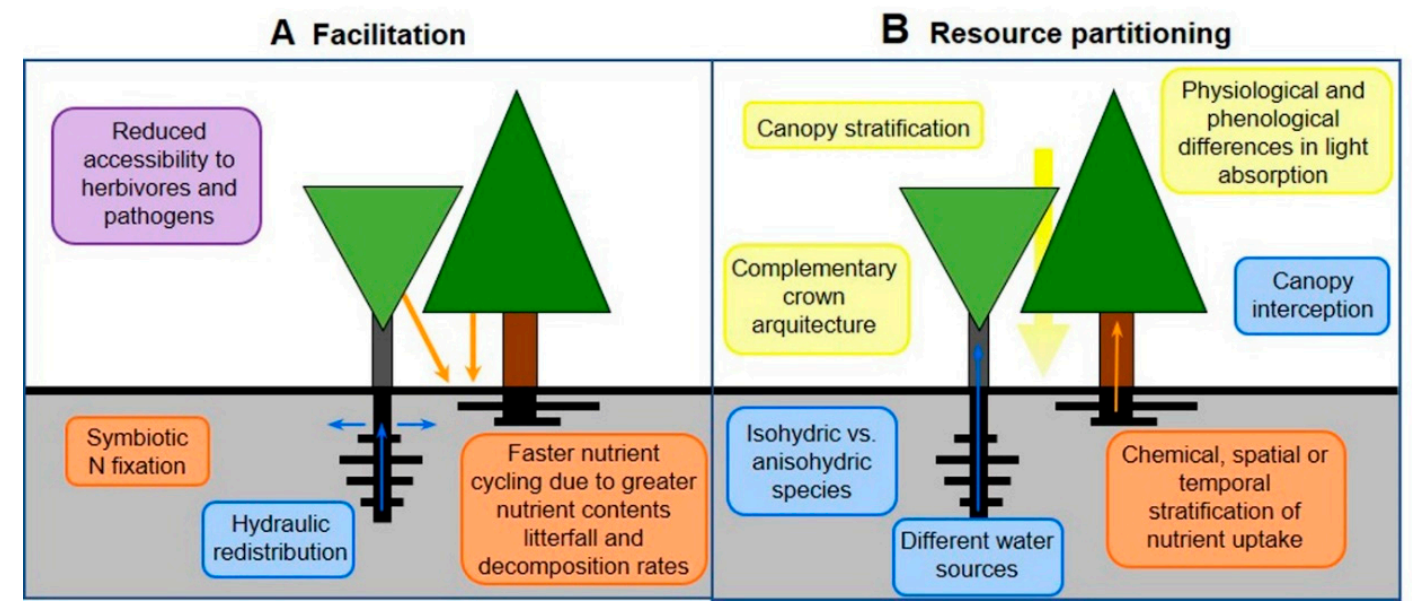

Figure 3. Illustration of underlying mechanisms that may lead to biodiversity effects divided into facilitation (A) and resource partitioning (B). Different colors represent processes related with nutrients (orange), water (blue), light (yellow), and biological agents (purple).

Some empirical studies indicate that more diverse forests tend to be less affected by droughts [135-138], although others did not find any beneficial effect $[120,139,140]$. After reviewing 28 studies that included 151 tree species, [141] stated that drought impacts on forests are modulated by tree diversity. However, the response is not necessarily positive, and it is dependent on multiple factors, including scale, environmental conditions, species identity, or management practices. Spatial changes in the interactions between a given combination of species have been found in many forests [142]. For instance, Fagus sylvatica L. underwent changing levels of stress in different regions of Europe with the same companion species [143]. Similarly, growth improvement of Pinus sylvestris L. with the admixture of F. sylvatica was dependent on site-specific conditions [102]. So environmental conditions in general, and climate in particular, play a key role determining the direction and magnitude of mixing effects on forest functioning [144-148]. Climate can modulate interactions among species directly by influencing the relative performance of each species [149], and indirectly through its effect on forest structure [150,151]. Among climatic factors, the study in [145] identified water availability as the most important factor modulating biodiversity effects.

It has been proposed that drought resistance is enhanced in mixed-species forests as long as net water-use partitioning or water-related facilitation processes take place [120], which depends on the functional traits of species involved in the mixture. The fact that responses to shifts in environmental conditions are mainly driven by species' identity effects rather than species diversity per se has been supported by recent studies $[108,109,124,131,143,152-154]$. Species-specific trade-offs between water conservation and C uptake $[56,57,120,143,155]$, as well as responses to $\mathrm{N}$ deposition in terms of growth, succession, and mortality $[77,87,108]$ have been broadly described.

In contrast to climate, studies assessing the influence of diversity on forest responses to $\mathrm{N}$ deposition are scarce. However, soil nutritional status has major influence on forests' growth and mortality responses to climate [109,111]. Such response is species-specific [109], conferring different 
competitive advantages and influencing species' interactions. From a grassland field experiment, the study in [156] shows that species-rich communities have greater growth response to the combined effect of rising $\mathrm{Ca}$ and $\mathrm{N}$ deposition than species-poor communities. However, whether such results can be extrapolated to forests' ecosystems is difficult to discern. For instance, the study in [108] identified different growth responses to $\mathrm{N}$ input as a function of the species' assemblages. Frequent shifts in understory and tree species composition has been also observed due to advantages for certain $\mathrm{N}$-demanding species $[29,77]$. Hence, selection effects might be important in mixtures exposed to high $\mathrm{N}$ deposition rates.

In addition, changes in the ratio of elements of tree biomass and other ecosystem compartments resulting from high $\mathrm{N}$ external inputs likely affect competitive interactions [157]. Conversely: there is empirical evidence that biodiversity influences nutrient cycling [158]. Therefore, to understand and predict forest responses to global change is important to consider nutrient availability, which in turn is affected by global change. A review of the influence of global change drivers on different phases of cycle of nutrients in forests is introduced in the following section.

\subsection{Nutrient Cycling}

Biogeochemical cycles of key elements such as C, N, or P determine productivity, respiration, and decomposition in terrestrial ecosystems $[17,71]$. At the same time, $\mathrm{C}$ storage in forest ecosystems is controlled by the biogeochemical cycles of $\mathrm{N}$ and P. Living organisms require elements in strict proportions to catalyze metabolic reactions and synthesize essential compounds with specific element ratios: i.e., stoichiometry of organisms [159]. Thus, biogeochemical cycles are biologically coupled due to conserved elemental stoichiometry of plants and microorganisms that drive $\mathrm{C}, \mathrm{N}$, and $\mathrm{P}$ cycles [160]. Elemental stoichiometry can be associated with important ecological processes and ecosystem traits, such as ecosystem composition and diversity [161], the ability of trees to adapt to environmental stress [36,162], composition of decomposer communities and litter decomposition rates [163-166], or growth rate properties [159]. The latter are reflected in the growth rate hypothesis, which states that organisms must increase the relative allocation of P to P-rich ribosomal RNA to meet the demands for protein synthesis required for rapid growth, which is possible under low N:P ratios in the environment [159].

However, global change has drastically affected the biogeochemical cycles of $C$ and nutrient elements of Earth's ecosystems [6]. Rapid environmental shifts have induced the imbalance among $\mathrm{C}, \mathrm{N}$, and $\mathrm{P}$ in ecosystems owing to different degrees of control by biological and geochemical processes $[24,160]$. Figure 4 summarizes possible mechanisms by which stoichiometry of trees can be modified as a consequence of increasing $\mathrm{Ca}$, climate change and high $\mathrm{N}$ inputs. Forest disturbances derived from extreme events such as fires or droughts may also have strong impacts on nutrient cycling [32]. Forest fires are a global phenomenon and over 300 million ha of forested lands are annually burned [113]. Nutrient-related effects of fires include acceleration of nutrient cycling, soil erosion, and volatilization of soil nutrients [32]. Forest susceptibility to fire depends on forest composition and structure [167]. Furthermore, the structure of litter layer and its decomposition dynamics are related to their flammability, so affecting fire spread and intensity [34].

Litterfall constitutes a major proportion of nutrient cycling between plant and soils in forest ecosystems [168]. Climatic conditions are closely linked to variations in litterfall annual production [169-173], seasonal patterns [118,171,174-176], and nutrient composition [118,177-180]. Hence, projected increasing temperatures and alterations of precipitation regimes will have striking consequences on litterfall dynamics. Altered soil nutrient availability, due to impaired $\mathrm{N}$ and $\mathrm{P}$ deposition [17], has been also found to modify litterfall composition through the impact on nutrient uptake, allocation, and resorption processes [112,181-183].

Decomposition rates are driven by multiple factors, such as soils, climate, decomposer community, and litter quality $[163,184]$. Litter quality has been identified as the most important factor controlling decomposition in two global meta-analysis $[185,186]$. Stoichiometric relationships of leaf litter are 
mainly the product of green leaves ratios and resorption $[187,188]$, which undergo significant variations as a response to global change [157]. Under high Ca C:N and C:P ratios generally increase [189], and evidences of positive relationships between rising $C a$ and N:P ratios have been found [190]. High N deposition rates are clearly associated with foliar N:P increases [17], and with decreases in N resorption, thus boosting litter N:P ratios [191,192]. Warming and drought have been proposed to increase C:N and $C: P$ ratios due to mechanisms associated with water conservation and increased nutrient use efficiencies [189], as well as, N:P ratios [157]. Globally, moist and warm conditions reduce and enhance $\mathrm{N}$ and $\mathrm{P}$ resorption efficiencies, respectively $[178,193]$. Furthermore, moisture conditions largely modulate the effect of rising $\mathrm{Ca}$ and $\mathrm{N}$ deposition on the stoichiometry of nutrient recycling [118,192].

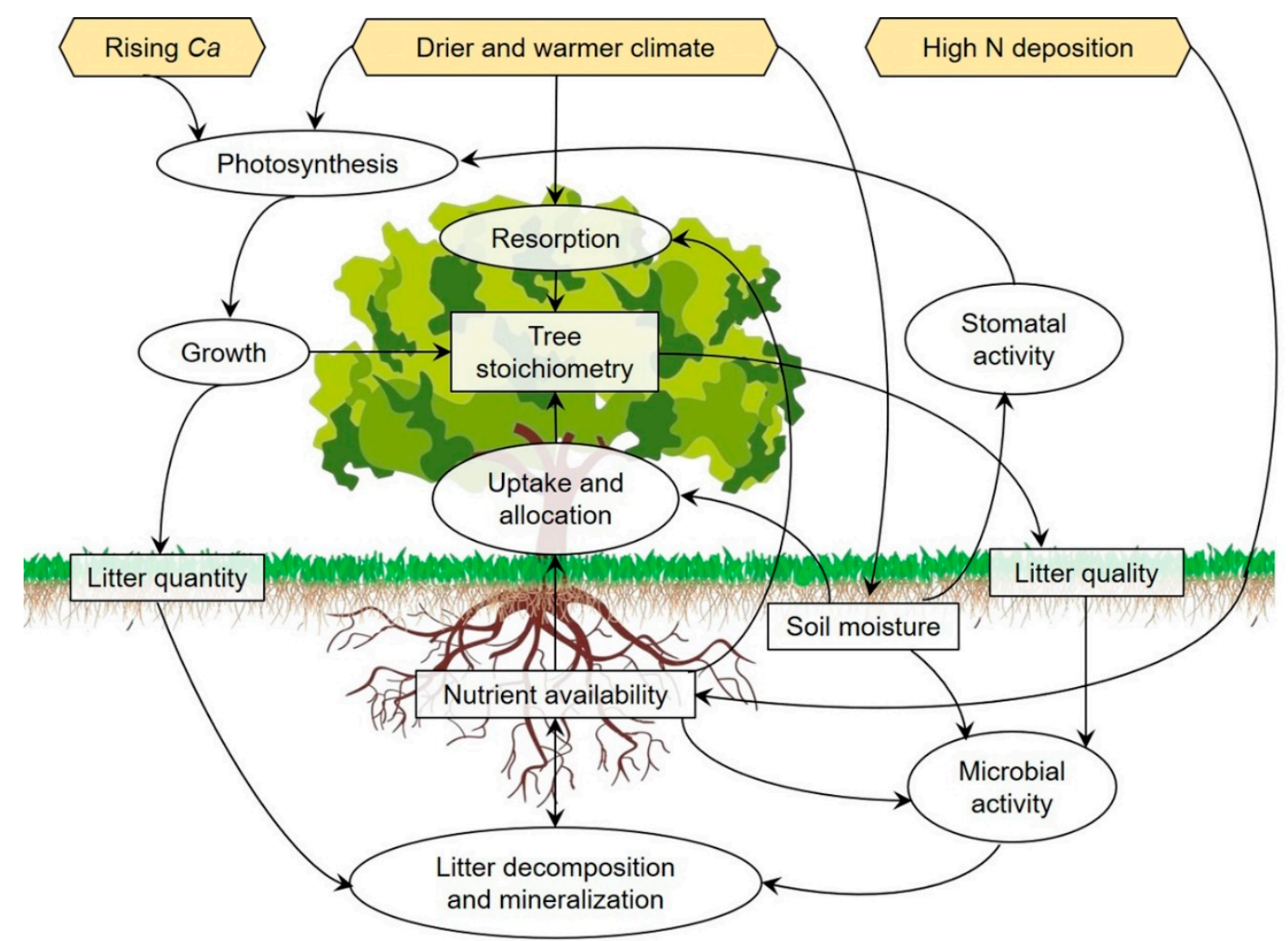

Figure 4. Conceptual diagram of the impacts of global change on processes controlling stoichiometry of trees. Yellow hexagons are global change drivers: increasing atmospheric $\mathrm{CO}_{2}$ concentration (Rising $\mathrm{Ca}$ ); climate change leading to drier and warmer conditions and high rates of atmospheric nitrogen (N) deposition; rectangles represent nutrient pools; and ellipses indicate biogeochemical processes.

The consumer-driven nutrient recycling theory predicts that the balance between litter stoichiometry and microbial element use efficiency directly determines nutrient recycling ratios [159]. Since soil microbes are largely homeostatic in terms of elemental stoichiometry, the stoichiometric imbalance between litterfall and microbial communities results in microbial activity limitation by a nutrient, and thus its immobilization in microbial biomass [192]. Decomposition rates have been negatively associated with high litter N:P ratios [194-196], hence the above-mentioned global change impacts on litter stoichiometry are expected to slow down nutrient return to soils. In fact, such phenomena has already been observed [197]. Furthermore, litterfall stoichiometry has been found to influence soil microorganism's diversity $[164,166]$.

Nutrient mineralization is further affected by drought since reduced soil water availability decreases microbial activity in soils and ion mobility [112]. Water status also determines the $\mathrm{CO}_{2}$ impact on mineralization [198]. Furthermore, warming increases net $\mathrm{N}$ mineralization and nitrification, and reduces soil P availability [199,200]. Finally, N deposition is known to impair litter decomposition, although the direction and degree of such response is dependent on interactions among deposition 
rates and litter quality [201]. High external $\mathrm{N}$ inputs also contribute to acidification and eutrophication of forest soils, thus leading to increased mineral nutrient losses by leaching to surface and ground waters (Figure 2A) [88,202].

\section{Forest Management under Global Change Scenarios}

\subsection{A Paradigm Shift}

Historically, forest management has been focused on a single dominant objective, most commonly timber production. In addition, an emphasis on increasing management efficiency by simplifying and homogenizing forest structures and operations has prevailed [203]. However, global change drivers and their interactions have boosted variability and uncertainty regarding future environmental, biological, and social conditions [204], together with a likely increase in the frequency and severity of disturbances and the appearance of new combinations of disturbances (see previous sections) [11,32]. Increased concerns about the provision of an assortment of ecosystem goods and services have led to a shift in focus of the attention from timber towards a wide range of economic, social, and ecological objectives [5,205]. They include conservation of biological diversity, maintenance of the productive capacity of forest ecosystems, maintenance of ecosystem health, conservation and maintenance of soil and water resources, maintenance of forest contribution to global C cycles, or maintenance and enhancement of long-term multiple social and economic benefits [206]. Hence, forest management and silvicultural practices need to be re-evaluated as the record of historical conditions cannot provide a straightforward guide for future silvicultural practices [207].

Industrial plantations are managed for maximum productivity and profitability, therefore, mono-cultures are preferred due to the uniform nature of the trees, ease of harvesting, wood quality attributes, processing of timber, accurate yield estimates, and other industry-related reasons. Instead, forests have been proposed to be managed as complex adaptive systems, because they are heterogeneous, highly dynamic, and contain many biotic and abiotic elements which interact across different levels of organizations with various feedback loops [208,209]. Forests are non-linear systems, highly sensitive to initial conditions, which makes precise predictions about their future behavior very difficult. They also show a hierarchical organization: elements at different levels interact to form an architecture that characterizes the system [210]. Adaptation of forest management to deal with global change is a dynamic process which involves system resilience and adaptability, not only from the ecological point of view but also from that the social, political, and economic. Thus, it shifts the importance away from exclusively direct aspects of productivity [11,211]. As future uncertainty increases, as it has been predicted under global change, the increased emphasis on resilience and adaptation will become more important.

A range of silvicultural systems to adapt forest management to global change have been proposed [212,213]. One example is the systemic silviculture management, whose strategies are based on an adaptive approach and continuous monitoring of the natural responses of each forest stand to silvicultural interventions [214]. Another proposal is the 'close-to-nature' approach, which promotes diversity regarding species mixtures, age structure, spatial scales, and heterogeneous stand structures as opposed to even-aged intensive industrial plantations [204,215]. Such silvicultural developments are focused on diversity and heterogeneity, which are more likely to cope with new conditions when subject to unpredictable stress or disturbance, and thus have been proposed for dealing with global change [216]. They imply different stand level adaptation measurements regarding forest regeneration, thinning, or harvesting. Thinning has been shown to partially mitigate the negative impacts of more arid conditions [122,217-219]. Enrichment sowing and planting in naturally regenerated stands, tending, or small-scale harvesting are adaptation options that can promote genetic and structural diversity and mixed species forests [213]. Mixed forests have been proposed as an adaptation strategy to cope with global change $[209,220]$ because they are considered more resistant to disturbances and extreme events [34,136,221], and may provide ecosystem goods and services 
more effectively than pure stands [222,223]. Mechanisms leading to greater multifunctionality under higher unpredictability in environmental conditions, as well as, some management considerations, are reviewed in the following section.

\subsection{Mixed-species Forests as Adaptation Strategy}

There is increasing evidence supporting that biodiversity fosters forest productivity on both regional [224-229] and global scales [146,230,231]. This increased productivity in mixtures compared to the weighted contribution of each species in pure stands is commonly referred as overyielding. In a global meta-analysis, the study in [230] found that mixtures are $24 \%$ more productive than pure forests, although a later study reported a global growth increment of $15 \%$ based on a more conservative analysis [146]. The diversity-productivity relationship represents an asymptotic curve [226,231], and it has been found to be highly dependent on other factors such as climate, local conditions, stand density and evenness, stand age, functional traits involved in the mixtures, etc. $[56,102,120,128,143,150,230,232-234]$.

Mixing effects vary along spatial gradients of resource availability [142] and over time due to environmental fluctuations [235] or changes in resource acquisition and species interactions with stand development [236]. Different responses to environmental shifting of the diversity-productivity relationships have been reported: increasing relaxation under more stressful conditions $[135,145,237]$ and increasing relaxation with improved site quality or climate conditions [102,139,227]. However, such contrasting findings can be explained under the theoretical framework proposed by [128]. It is an extension of the stress gradient hypothesis [125], and states that when species interactions improve the availability, uptake or use efficiency of the resource that is becoming more limiting along a spatial or temporal gradient, relaxation also tends to increase along that gradient $[142,238,239]$. See Figure 3 for examples of mechanisms of relaxation regarding different resources.

Therefore, positive biodiversity effects on forest productivity arise only when relaxation processes occur in regard to the more limiting factor, which depends on the functional traits of species included in a mixture (see Section 3.2. for further discussion). In general, if underlying mechanisms of species interactions result in improved availability, uptake, or water (nutrient) use efficiency, biodiversity effects will become more positive along decreasing gradients of water (nutrients) availability. Otherwise, forests productivity will increase as soil properties or climate improve and denser canopy can develop if light interception is enhanced as a result of species interaction (Figure 5) [128,142]. As a case in point, the authors in [102] found in a tree-level study that although the admixture of F. sylvatica increased WUE of P. sylvestris, it only translated into growth improvements under mesic conditions. Growing together with F. sylvatica increased light absorption of P. sylvestris [240] as a result of enhanced morphological variability, crown extension, and canopy space filling [151,241]. It is likely that such beneficial light-related mixing effects on $P$. sylvestris were overridden by competition for water resources with F. sylvatica in drought-prone environments as faster depletion of soil water and higher canopy interception have been reported in mixtures $[139,219]$. Such results are in agreement with other studies [122,219,242] and they are supported by stand-level simulations at longer time scales [243].

Higher stability of mixed forests against environmental fluctuations than single-species forests has been reported in empirical [244-246] and modeling approaches [247,248]. Ecological stability involves several concepts, such as resilience, resistance, or persistence of ecosystem properties [249]. The diversity-stability relationship, which assess temporal stability of productivity, may arise from different mechanisms. Asynchrony in the species response to environmental fluctuations has been identified as a key factor in the stabilizing effect of diversity $[250,251]$ and it is in accordance with the insurance hypothesis [252]. Species asynchrony generates asynchronous population dynamics that enables productivity compensation among species and promote productivity stability at community level [251]. Competitive reduction and facilitation resulting from species interactions also contribute to stability through the overyielding effect, because increased abundance or biomass reduced the risk of stochastic demographic dynamics [250]. 
Species' interactions may also promote resistance against natural disturbances such as drought [136,253,254], but see [120,139,143]; fire [255]; windstorms [256]; or insect herbivory [257]. Several mechanisms have been proposed to enhance the resistance of mixed forests. These include complementarity on resistance traits, reduction of fuel and food resources, or diminished accessibility to target trees [34]. Likewise, increased resilience to extreme events have been reported in more diverse forests [136,258]. Further forest functions and services that appear to improve under increasing diversity comprise C storage capacity [259], ecosystem health and vitality [220,221], or reduced economic risks [260].

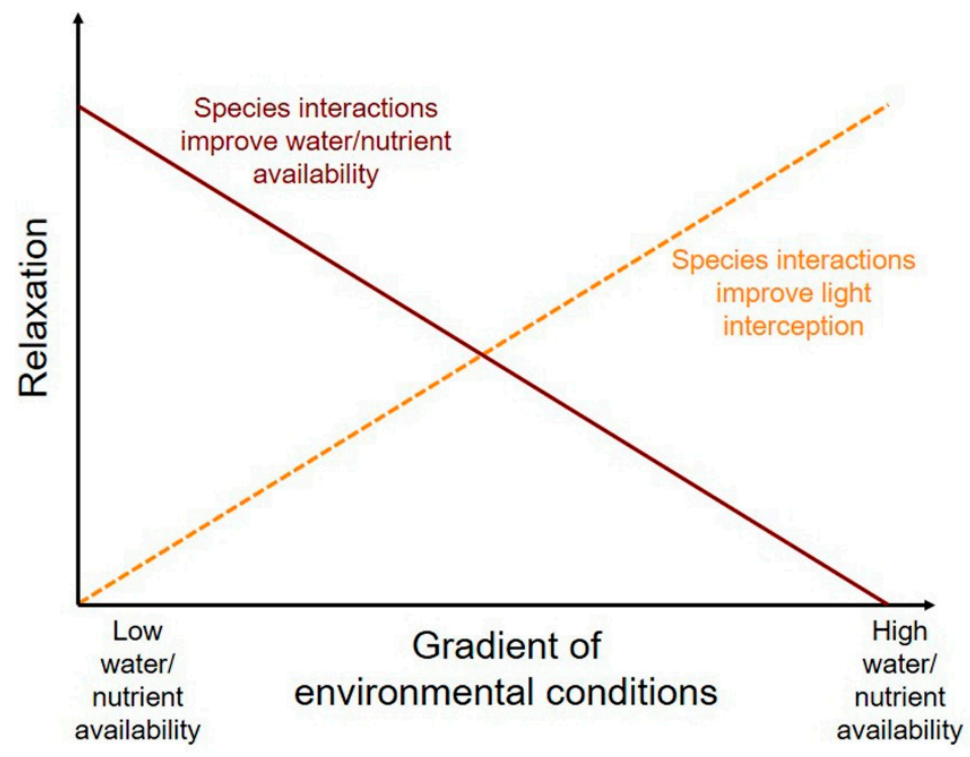

Figure 5. Conceptual framework for variation of mixing effects along spatial or temporal gradients of resource availability (based on [142] and [128]). If species' interactions enhance relaxation (sensu [129]) regarding water or nutrients, positive biodiversity effects will increase along decreasing gradients of water or nutrients availability (solid dark red line). On the contrary, light-related interactions will result in increased forest productivity as site quality and climate improve (dashed orange line).

However, despite the important benefits described above, managing mixed forests can be more complex than managing pure plantations because the provision of multiple services needs to be optimized, such as productivity, sustaining biodiversity, or climate change mitigation. Managing forests in a mixed condition requires more complicated operations, there are very few instructions for designing and managing mixtures, and the right combination of species and site conditions need to be achieved [261]. Indeed, the selection of the adequate species combination with different functional traits that enhance relaxation regarding the more limiting factor of a given site appears to be more important than increasing only the number of species in the stand $[34,129,243,258]$. Spatial scale is a further issue to be considered when planning mixed forest management. Positive biodiversity effects have been associated with local neighborhood species interactions rather than processes acting at stand level [229]. Hence, mixing configurations with close inter-specific intermingling can maximize benefits of species mixing, which has been supported in field studies [262] and modeling approaches [263], instead of mixing pure patches at the stand or landscape level. Moreover, planting schemes and/or thinning operations can control stand density in managed mixed stands. The degree and intensity of species interactions is modulated by stand density, so that at low densities interactions may not be strong enough to impact productivity, while at high densities competition can outweigh relaxation $[128,150]$. Designing management plans for mixtures may become even more complicated due to the lack of long-term field studies covering the whole lifespan of forest stands, the spatial and temporal changes in species interactions, and the uncertainty in changing environmental conditions. As a consequence, forest growth models represent a useful means of understanding and predicting forest functioning and 
they are a valuable decision-support tool in forest management [264]. Hybrid models, which combine ecological processes and empirical data, are able to simulate the effect of species interactions of novel species combinations and proportions under novel environmental conditions, disturbances regimes, and/or management interventions [265].

\section{Conclusions}

Human-induced factors have led to the alteration of global biogeochemical cycles and climate. Increasing uncertainty is predicted regarding future environmental conditions with significant impacts on forests functioning and the range of services provided by forests. A multidisciplinary approach is needed to understand the complex effects of global change drivers on different levels of forests' organization. Studies downscaled to small levels of organization (i.e., organs, individuals) are important to elucidate mechanisms underlying community or landscape level patterns [129].

Nutritional status, $\mathrm{C}$ metabolism, and water balance of trees are affected by global change, so forest functions, such as productivity or drought resistance, will be likely modified. It is noteworthy that such tree and stand response is modulated by interactions among species. In general, enhanced performance of more diverse forests has been reported, although it depends on species combination, rather than on the number of species. Environmental conditions also impact species' interactions and the concomitant effect of rising $\mathrm{CO}_{2}$ concentration, increasing drought frequency and intensity, and high $\mathrm{N}$ deposition rates, which alter population and community dynamics. Complex interactions among global change impacts have been also described on ecosystem processes that control the transfer of matter and cycling of nutrients. Thus, highlighting the importance of multi-factor studies using both empirical and modeling approaches.

Therefore, forest management must adapt to hardly predictable future environmental conditions, and so the emphasis shifts from productivity towards forests' resistance and resilience. Encouragement of mixed forests, which enhance functional diversity and structural heterogeneity, has been proposed as an adaptation strategy to cope with global change. It is supported by the positive relationships found between diversity and productivity, stability, resistance, or resilience of forests. Nonetheless, there are important issues to consider when designing management plans of mixed forests, such species identity, mixing patterns, or stand density.

Funding: This research received no external funding.

Acknowledgments: The author wish to thank Juan A. Blanco and J. Bosco Imbert for their support and advice in writing the manuscript. E.G.A. was funded by the TIMENUTRIENT project (ref. AGL2016-76463-P) granted by the Spanish Ministry of Economy and Competitiveness.

Conflicts of Interest: The author declares no conflict of interest.

\section{References}

1. FAO. State of the World's Forests 2016; Forests and Agriculture: Land-Use Challenges and Opportunities; FAO: Rome, Italy, 2016; Volume 45, ISBN 978-92-5-109208-8.

2. Crowther, T.W.; Glick, H.B.; Covey, K.R.; Bettigole, C.; Maynard, D.S.; Thomas, S.M.; Smith, J.R.; Hintler, G.; Duguid, M.C.; Amatulli, G.; et al. Mapping tree density at a global scale. Nature 2015, 525, 201-205. [CrossRef] [PubMed]

3. Pan, Y.; Birdsey, R.A.; Phillips, O.L.; Jackson, R.B. The Structure, distribution, and biomass of the world's forests. Annu. Rev. Ecol. Evol. Syst. 2013, 44, 593-622. [CrossRef]

4. Anderson-Teixeira, K.J.; Davies, S.J.; Bennett, A.C.; Gonzalez-Akre, E.B.; Muller-Landau, H.C.; Joseph Wright, S.; Abu Salim, K.; Almeyda Zambrano, A.M.; Alonso, A.; Baltzer, J.L.; et al. CTFS-ForestGEO: A worldwide network monitoring forests in an era of global change. Glob. Chang. Biol. 2015, 21, 528-549. [CrossRef] [PubMed]

5. Ellison, D.; Morris, C.E.; Locatelli, B.; Sheil, D.; Cohen, J.; Murdiyarso, D.; Gutierrez, V.; van Noordwijk, M.; Creed, I.F.; Pokorny, J.; et al. Trees, forests and water: Cool insights for a hot world. Glob. Environ. Chang. 2017, 43, 51-61. [CrossRef] 
6. Vitousek, P.M.; Mooney, H.A.; Lubchenco, J.; Melillo, J.M. Human Domination of Earth's Ecosystems. Science 1997, 277, 494-499. [CrossRef]

7. Rockström, J.; Steffen, W.; Noone, K.; Persson, Å.; Chapin III, F.S.; Lambin, E.F.; Lenton, T.M.; Scheffer, M.; Folke, C.; Schellnhuber, H.J.; et al. A safe operating space for humanity. Nature 2009, 461, 472. [CrossRef] [PubMed]

8. Sala, O.E.; Iii, F.S.C.; Armesto, J.J.; Berlow, E.; Dirzo, R.; Huber-sanwald, E.; Huenneke, L.F.; Robert, B.; Kinzig, A.; Leemans, R.; et al. Global biodiversity scenarios for the year 2100. Science 2000, 287, 1770-1775. [CrossRef] [PubMed]

9. Aber, J.; Neilson, R.P.; McNulty, S.; Lenihan, J.M.; Bachelet, D.; Drapek, R.J. Forest processes and global environmental change: Predicting the effects of individual and multiple stressors. Bioscience 2001, 51, 735-751. [CrossRef]

10. Elser, J.J.; Fagan, W.F.; Kerkhoff, A.J.; Swenson, N.G.; Enquist, B.J. Biological stoichiometry of plant production: Metabolism, scaling and ecological response to global change. New Phytol. 2010, 186, 593-608. [CrossRef]

11. Millar, C.I.; Stephenson, N.L. Temperate forest health in an era of emerging megadisturbance. Science 2015, 349, 823-826. [CrossRef]

12. IPCC. 2013 AR5 The Physical Science Basis. Summary for Policymakers. In Climate Change 2013: The Physical Science Basis; Contribution of Working Group I to the Fifth Assessment Report of the Intergovernmental Panel on Climate Change; Cambridge University Press: Cambridge, UK; New York, NY, USA, 2013; ISBN 978-1107661820.

13. Nelson, G.C.; Bennett, E.; Berhe, A.A.; Cassman, K.G.; Defries, R.; Dietz, T.; Dobermann, A.R.; Dobson, A.; Janetos, A.; Levy, M.; et al. Anthropogenic drivers of ecosystem change: An Overview. Ecol. Soc. 2006, 11, 29. [CrossRef]

14. Zhang, X.; Zwiers, F.W.; Hegerl, G.C.; Lambert, F.H.; Gillett, N.P.; Solomon, S.; Stott, P.A.; Nozawa, T. Detection of human influence on twentieth-century precipitation trends. Nature 2007, 448, 461. [CrossRef] [PubMed]

15. Trenberth, K.E. Changes in precipitation with climate change. Clim. Res. 2011, 47, 123-138. [CrossRef]

16. Hoerling, M.P.; Hurrell, J.W.; Xu, T. Tropical origins for recent North Atlantic climate change. Science 2001, 292, 90-92. [CrossRef] [PubMed]

17. Peñuelas, J.; Poulter, B.; Sardans, J.; Ciais, P.; Van Der Velde, M.; Bopp, L.; Boucher, O.; Godderis, Y.; Hinsinger, P.; Llusia, J.; et al. Human-induced nitrogen-phosphorus imbalances alter natural and managed ecosystems across the globe. Nat. Commun. 2013, 4, 2934. [CrossRef] [PubMed]

18. Fowler, D.; Steadman, C.E.; Stevenson, D.; Coyle, M.; Rees, R.M.; Skiba, U.M.; Sutton, M.A.; Cape, J.N.; Dore, A.J.; Vieno, M.; et al. Effects of global change during the 21st century on the nitrogen cycle. Atmos. Chem. Phys. 2015, 15, 13849-13893. [CrossRef]

19. Schmitz, A.; Sanders, T.G.M.; Bolte, A.; Bussotti, F.; Dirnböck, T.; Johnson, J.; Peñuelas, J.; Pollastrini, M.; Prescher, A.K.; Sardans, J.; et al. Responses of forest ecosystems in Europe to decreasing nitrogen deposition. Environ. Pollut. 2019, 244, 980-994. [CrossRef]

20. Galloway, J.N.; Dentener, F.J.; Capone, D.G.; Boyer, E.W.; Howarth, R.W.; Seitzinger, S.P.; Asner, G.P.; Cleveland, C.C.; Green, P.A.; Holland, E.A.; et al. Nitrogen cycles: Past, present, and future. Biogeochemistry 2004, 70, 153-226. [CrossRef]

21. Engardt, M.; Simpson, D.; Schwikowski, M.; Granat, L. Deposition of sulphur and nitrogen in Europe 1900-2050. Model calculations and comparison to historical observations. Tellus B Chem. Phys. Meteorol. 2017, 69. [CrossRef]

22. Lamarque, J.-F.; Kiehl, J.T.; Brasseur, G.P.; Butler, T.; Cameron-Smith, P.; Collins, W.D.; Collins, W.J.; Granier, C.; Hauglustaine, D.; Hess, P.G.; et al. Assessing future nitrogen deposition and carbon cycle feedback using a multimodel approach: Analysis of nitrogen deposition. J. Geophys. Res. Atmos. 2005, 110. [CrossRef]

23. Wei, X.; Blanco, J.A.; Jiang, H.; Kimmins, J.P.H. Effects of nitrogen deposition on carbon sequestration in Chinese fir forest ecosystems. Sci. Total Environ. 2012, 416, 351-361. [CrossRef] [PubMed]

24. Peñuelas, J.; Sardans, J.; Rivas-ubach, A.; Janssens, I.A. The human-induced imbalance between C, N and P in Earth's life system. Glob. Chang. Biol. 2012, 18, 3-6. [CrossRef]

25. Erisman, J.W.; Grennfelt, P.; Sutton, M. The European perspective on nitrogen emission and deposition. Environ. Int. 2003, 29, 311-325. [CrossRef] 
26. Slootweg, J.; Posch, M.; Hettelingh, J.P. Modelling and Mapping the Impacts of Atmospheric Deposition of Nitrogen and Sulphur: CCE Status Report 2015; National Institute for Public Health and the Environment: Bilthoven, The Netherlands, 2016; ISBN 978-90-6960-283-7.

27. Aber, J.D.; Melillo, J.M.; Nadelhoffer, K.J.; Pastor, J.; Boone, R.D. Factors controlling nitrogen cycling and nitrogen saturation in northern temperate forest ecosystems. Ecol. Appl. 1991, 1, 303-315. [CrossRef] [PubMed]

28. Magill, A.H.; Aber, J.D.; Hendricks, J.J.; Bowden, R.D.; Melillo, J.M.; Steudler, P.A. Biogeochemical response of forest ecosystems to simulated chronic nitrogen deposition. Ecol. Appl. 1997, 7, 402-415. [CrossRef]

29. Bobbink, R.; Hicks, K.; Galloway, J.; Spranger, T.; Alkemade, R.; Ashmore, M.; Bustamante, M.; Cinderby, S.; Davidson, E.; Dentener, F.; et al. Global assessment of nitrogen deposition effects on terrestrial plant diversity: A synthesis. Ecol. Appl. 2010, 20, 30-59. [CrossRef]

30. Boden, T.A.; Marland, G.; Andres, R.J. Global, Regional, and National Fossil-Fuel $\mathrm{CO}_{2}$ Emissions; Carbon Dioxide Information Analysis Center, Oak Ridge National Laboratory, U.S. Department of Energy: Oak Ridge, TN, USA, 2010.

31. Morice, C.P.; Kennedy, J.J.; Rayner, N.A.; Jones, P.D. Quantifying uncertainties in global and regional temperature change using an ensemble of observational estimates: The HadCRUT4 data set. J. Geophys. Res. Atmos. 2012, 117. [CrossRef]

32. Dale, V.; Joyce, L.; Mcnulty, S.; Neilson, R.; Ayres, M.; Flannigan, M.; Hanson, P.; Irland, L.; Lugo, A.; Peterson, C.; et al. Climate change and forest disturbances. Bioscience 2001, 51, 723-734. [CrossRef]

33. Lloyd, J. The $\mathrm{CO}_{2}$ dependence of photosynthesis, plant growth responses to elevated $\mathrm{CO}_{2}$ concentrations and their interaction with soil nutrient status, II. Temperate and boreal forest productivity and the combined effects of increasing $\mathrm{CO}_{2}$ concentrations and increased nitrogen deposition at alobal scale. Funct. Ecol. 1999, 13, 439-459.

34. Jactel, H.; Bauhus, J.; Boberg, J.; Bonal, D.; Castagneyrol, B.; Gardiner, B.; Gonzalez-Olabarria, J.R.; Koricheva, J.; Meurisse, N.; Brockerhoff, E.G. Tree Diversity Drives Forest Stand Resistance to Natural Disturbances. Curr. For. Rep. 2017, 3, 223-243. [CrossRef]

35. Lim, H.; Oren, R.; Linder, S.; From, F.; Nordin, A.; Fahlvik, N.; Lundmark, T.; Näsholm, T. Annual climate variation modifies nitrogen induced carbon accumulation of Pinus sylvestris forests. Ecol. Appl. 2017, 27, 1838-1851. [CrossRef] [PubMed]

36. Sardans, J.; Grau, O.; Chen, H.Y.H.; Janssens, I.A.; Ciais, P.; Piao, S.; Peñuelas, J. Changes in nutrient concentrations of leaves and roots in response to global change factors. Glob. Chang. Biol. 2017, 23, 3849-3856. [CrossRef] [PubMed]

37. Gedalof, Z.; Berg, A.A. Tree ring evidence for limited direct $\mathrm{CO}_{2}$ fertilization of forests over the 20th century. Glob. Biogeochem. Cycles 2010, 24, 2-7. [CrossRef]

38. Ainsworth, E.A.; Rogers, A. The response of photosynthesis and stomatal conductance to rising $\left[\mathrm{CO}_{2}\right]$ : Mechanisms and environmental interactions. Plant Cell Environ. 2007, 30, 258-270. [CrossRef] [PubMed]

39. Bernacchi, C.J.; Bagley, J.E.; Serbin, S.P.; Ruiz-Vera, U.M.; Rosenthal, D.M.; Vanloocke, A. Modelling C3 photosynthesis from the chloroplast to the ecosystem. Plant Cell Environ. 2013, 36, 1641-1657. [CrossRef] [PubMed]

40. Norby, R.J.; Wullschleger, S.D.; Gunderson, C.A.; Johnson, D.W.; Ceulemans, R. Tree responses to rising $\mathrm{CO}_{2}$ in field experiments: Implications for the future forest. Plant Cell Environ. 1999, 22, 683-714. [CrossRef]

41. Katul, G.; Manzoni, S.; Palmroth, S.; Oren, R. A stomatal optimization theory to describe the effects of atmospheric $\mathrm{CO}_{2}$ on leaf photosynthesis and transpiration. Ann. Bot. 2010, 105, 431-442. [CrossRef]

42. Farquhar, G.D.; Ehleringer, J.R.; Hubick, K.T. Discrimination and photosynthesis. Annu. Rev. Plant Biol. 1989, 40, 503-537. [CrossRef]

43. Körner, C. Biosphere responses to $\mathrm{CO}_{2}$ enrichment. Ecol. Appl. 2000, 10, 1590-1619.

44. Huang, J.G.; Bergeron, Y.; Denneler, B.; Berninger, F.; Tardif, J. Response of forest trees to increased atmospheric $\mathrm{CO}_{2}$. Crit. Rev. Plant Sci. 2007, 26, 265-283. [CrossRef]

45. Fatichi, S.; Leuzinger, S.; Paschalis, A.; Langley, J.A.; Donnellan Barraclough, A.; Hovenden, M.J. Partitioning direct and indirect effects reveals the response of water-limited ecosystems to elevated $\mathrm{CO}_{2}$. Proc. Natl. Acad. Sci. USA 2016, 113, 12757-12762. [CrossRef] [PubMed]

46. Holden, P.B.; Edwards, N.R.; Gerten, D.; Schaphoff, S. A model-based constraint on $\mathrm{CO}_{2}$ fertilisation. Biogeosciences 2013, 10, 339-355. [CrossRef] 
47. Lamarche, V.C.; Graybill, D.A.; Fritts, H.C.; Rose, M.R. Increasing atmospheric carbon dioxide: Tree ring evidence for growth enhancement in natural vegetation. Science 1984, 225, 1019-1021. [CrossRef] [PubMed]

48. Soulé, P.T.; Knapp, P.A. Radial growth rate increases in naturally occurring ponderosa pine trees: A late-20th century $\mathrm{CO}_{2}$ fertilization effect? New Phytol. 2006, 171, 379-390. [CrossRef] [PubMed]

49. Koutavas, A. Late 20th century growth acceleration in greek firs (Abies cephalonica) from Cephalonia Island, Greece: $\mathrm{A} \mathrm{CO}_{2}$ fertilization effect? Dendrochronologia 2008, 26, 13-19. [CrossRef]

50. Martínez-Vilalta, J.; López, B.C.; Adell, N.; Badiella, L.; Ninyerola, M. Twentieth century increase of Scots pine radial growth in NE Spain shows strong climate interactions. Glob. Chang. Biol. 2008, 14, 2868-2881. [CrossRef]

51. Sánchez-Salguero, R.; Camarero, J.J.; Hevia, A.; Madrigal-González, J.; Linares, J.C.; Ballesteros-Canovas, J.A.; Sánchez-Miranda, A.; Alfaro-Sánchez, R.; Sangüesa-Barreda, G.; Galván, J.D.; et al. What drives growth of Scots pine in continental Mediterranean climates: Drought, low temperatures or both? Agric. For. Meteorol. 2015, 206, 151-162. [CrossRef]

52. Peñuelas, J.; Hunt, J.M.; Ogaya, R.; Jump, A.S. Twentieth century changes of tree-ring $\delta 13 C$ at the southern range-edge of Fagus sylvatica: Increasing water-use efficiency does not avoid the growth decline induced by warming at low altitudes. Glob. Chang. Biol. 2008, 14, 1076-1088. [CrossRef]

53. Peñuelas, J.; Canadell, J.G.; Ogaya, R. Increased water-use efficiency during the 20th century did not translate into enhanced tree growth. Glob. Ecol. Biogeogr. 2011, 20, 597-608. [CrossRef]

54. Linares, J.C.; Camarero, J.J. From pattern to process: Linking intrinsic water-use efficiency to drought-induced forest decline. Glob. Chang. Biol. 2012, 18, 1000-1015. [CrossRef]

55. Bader, M.K.F.; Leuzinger, S.; Keel, S.G.; Siegwolf, R.T.W.; Hagedorn, F.; Schleppi, P.; Körner, C. Central European hardwood trees in a high- $\mathrm{CO}_{2}$ future: Synthesis of an 8-year forest canopy $\mathrm{CO}_{2}$ enrichment project. J. Ecol. 2013, 101, 1509-1519. [CrossRef]

56. Silva, L.C.R.; Anand, M. Probing for the influence of atmospheric $\mathrm{CO}_{2}$ and climate change on forest ecosystems across biomes. Glob. Ecol. Biogeogr. 2013, 22, 83-92. [CrossRef]

57. Granda, E.; Rossatto, D.R.; Camarero, J.J.; Voltas, J.; Valladares, F. Growth and carbon isotopes of Mediterranean trees reveal contrasting responses to increased carbon dioxide and drought. Oecologia 2014, 174, 307-317. [CrossRef] [PubMed]

58. Camarero, J.J.; Gazol, A.; Tardif, J.C.; Conciatori, F. Attributing forest responses to global-change drivers: Limited evidence of a $\mathrm{CO}_{2}$-fertilization effect in Iberian pine growth. J. Biogeogr. 2015, 42, 2220-2233. [CrossRef]

59. Silva, L.C.R.; Anand, M.; Leithead, M.D. Recent widespread tree growth decline despite increasing atmospheric $\mathrm{CO}_{2}$. PLoS ONE 2010, 5, e11543. [CrossRef] [PubMed]

60. Brienen, R.J.W.; Gloor, E.; Zuidema, P.A. Detecting evidence for $\mathrm{CO}_{2}$ fertilization from tree ring studies: The potential role of sampling biases. Glob. Biogeochem. Cycles 2012, 26. [CrossRef]

61. Ainsworth, E.A.; Rogers, A.; Nelson, R.; Long, S.P. Testing the "source-sink" hypothesis of down-regulation of photosynthesis in elevated $\left[\mathrm{CO}_{2}\right]$ in the field with single gene substitutions in Glycine max. Agric. For. Meteorol. 2004, 122, 85-94. [CrossRef]

62. Aranjuelo, I.; Pérez, P.; Hernández, L.; Irigoyen, J.J.; Zita, G.; Martínez-Carrasco, R.; Sánchez-Díaz, M. The response of nodulated alfalfa to water supply, temperature and elevated $\mathrm{CO}_{2}$ : Photosynthetic downregulation. Physiol. Plant. 2005, 123, 348-358. [CrossRef]

63. Ward, J.K.; Harris, J.M.; Cerling, T.E.; Wiedenhoeft, A.; Lott, M.J.; Dearing, M.-D.; Coltrain, J.B.; Ehleringer, J.R. Carbon starvation in glacial trees recovered from the La Brea tar pits, southern California. Proc. Natl. Acad. Sci. USA 2005, 102, 690-694. [CrossRef]

64. Salzer, M.W.; Hughes, M.K.; Bunn, A.G.; Kipfmueller, K.F. Recent unprecedented tree-ring growth in bristlecone pine at the highest elevations and possible causes. Proc. Natl. Acad. Sci. USA 2009, 106, 20348-20353. [CrossRef]

65. Ise, T.; Moorcroft, P.R. Simulating boreal forest dynamics from perspectives of ecophysiology, resource availability, and climate change. Ecol. Res. 2010, 25, 501-511. [CrossRef]

66. Luo, Y.; Su, B.; Currie, W.S.; Dukes, J.S.; Finzi, A.; Hartwig, U.; Hungate, B.; Mc Murtrie, R.E.; Oren, R.; Parton, W.J.; et al. Progressive nitrogen limitation of ecosystem responses to rising atmospheric carbon dioxide. Bioscience 2004, 54, 731-739. [CrossRef] 
67. Norby, R.J.; Warren, J.M.; Iversen, C.M.; Medlyn, B.E.; McMurtrie, R.E. $\mathrm{CO}_{2}$ enhancement of forest productivity constrained by limited nitrogen availability. Proc. Natl. Acad. Sci. USA 2010, 107, 19368-19373. [CrossRef] [PubMed]

68. Sun, J.; Dai, W.; Peng, B.; Liu, J.; He, T.; Jiang, P.; Han, S.; Bai, E. Does the accelerated soil N cycling sustain N demand of Quercus mongolica after decade-long elevated $\mathrm{CO}_{2}$ treatment? Biogeochemistry 2018, 139, 197-213. [CrossRef]

69. Reich, P.B.; Hungate, B.A.; Luo, Y. Carbon-nitrogen interactions in terrestrial ecosystems in response to rising atmospheric carbon dioxide. Annu. Rev. Ecol. Evol. Syst. 2006, 37, 611-636. [CrossRef]

70. Walker, T.W.; Syers, J.K. The fate of phosphorus during pedogenesis. Geoderma 1976, 15, 1-19. [CrossRef]

71. Vitousek, P.M.; Porder, S.; Houlton, B.Z.; Chadwick, O.A. Terrestrial phosphorus limitation: Mechanisms, implications, and nitrogen-phosphorus interactions. Ecol. Appl. 2010, 20, 5-15. [CrossRef]

72. Townsend, A.R.; Braswell, B.H.; Holland, E.A.; Penner, J.E. Spatial and temporal patterns in terrestrial carbon storage due to deposition of fossil fuel nitrogen. Ecol. Appl. 1996, 6, 806-814. [CrossRef]

73. Emmett, B.A. The impact of nitrogen on forest soils and feedbacks on tree growth. Water Air Soil Pollut. 1999, 116, 65-74. [CrossRef]

74. De Vries, W.; Reinds, G.J.; Gundersen, P.; Sterba, H. The impact of nitrogen deposition on carbon sequestration in European forests and forest soils. Glob. Chang. Biol. 2006, 12, 1151-1173. [CrossRef]

75. Hyvönen, R.; Persson, T.; Andersson, S.; Olsson, B.; Ågren, G.I.; Linder, S. Impact of long-term nitrogen addition on carbon stocks in trees and soils in northern Europe. Biogeochemistry 2008, 89, 121-137. [CrossRef]

76. LeBauer, D.S.; Treseder, K.K. Nitrogen limitation of net primary productivity. Ecology 2008, 89, 371-379. [CrossRef] [PubMed]

77. Thomas, R.Q.; Canham, C.D.; Weathers, K.C.; Goodale, C.L. Increased tree carbon storage in response to nitrogen deposition in the US. Nat. Geosci. 2010, 3, 13-17. [CrossRef]

78. Pretzsch, H.; Biber, P.; Schütze, G.; Uhl, E.; Rötzer, T. Forest stand growth dynamics in Central Europe have accelerated since 1870. Nat. Commun. 2014, 5, 4967. [CrossRef] [PubMed]

79. Schulte-Uebbing, L.; de Vries, W. Global-scale impacts of nitrogen deposition on tree carbon sequestration in tropical, temperate, and boreal forests: A meta-analysis. Glob. Chang. Biol. 2018, 24, e416-e431. [CrossRef] [PubMed]

80. Janssens, I.A.; Luyssaert, S. Carbon cycle: Nitrogen's carbon bonus. Nat. Geosci. 2009, 2, 318-319. [CrossRef]

81. Fleischer, K.; Rebel, K.T.; Van Der Molen, M.K.; Erisman, J.W.; Wassen, M.J.; Van Loon, E.E.; Montagnani, L.; Gough, C.M.; Herbst, M.; Janssens, I.A.; et al. The contribution of nitrogen deposition to the photosynthetic capacity of forests. Glob. Biogeochem. Cycles 2013, 27, 187-199. [CrossRef]

82. Lim, H.; Oren, R.; Palmroth, S.; Tor-ngern, P.; Mörling, T.; Näsholm, T.; Lundmark, T.; Helmisaari, H.; Leppälammi-Kujansuu, J.; Linder, S. Inter-annual variability of precipitation constrains the production response of boreal Pinus sylvestris to nitrogen fertilization. For. Ecol. Manag. 2015, 348, 31-45. [CrossRef]

83. Meyer-Grünefeldt, M.; Friedrich, U.; Klotz, M.; Von Oheimb, G.; Härdtle, W. Nitrogen deposition and drought events have non-additive effects on plant growth-Evidence from greenhouse experiments. Plant Biosyst.-Int. J. Deal. All Asp. Plant Biol. 2015, 149, 424-432. [CrossRef]

84. Högberg, P.; Fan, H.; Quist, M.; Binkley, D.; Tamm, C.O. Tree growth and soil acidification in response to 30 years of experimental nitrogen loading on boreal forest. Glob. Chang. Biol. 2006, 12, 489-499. [CrossRef]

85. de Vries, W.; Du, E.; Butterbach-Bahl, K. Short and long-term impacts of nitrogen deposition on carbon sequestration by forest ecosystems. Curr. Opin. Environ. Sustain. 2014, 9, 90-104. [CrossRef]

86. Tian, H.; Lu, C.; Ciais, P.; Michalak, A.M.; Canadell, J.G.; Saikawa, E.; Huntzinger, D.N.; Gurney, K.R.; Sitch, S.; Zhang, B.; et al. The terrestrial biosphere as a net source of greenhouse gases to the atmosphere. Nature 2016, 531, 225. [CrossRef] [PubMed]

87. Magill, A.H.; Aber, J.D.; Currie, W.S.; Nadelhoffer, K.J.; Martin, M.E.; McDowell, W.H.; Melillo, J.M.; Steudler, P. Ecosystem response to 15 years of chronic nitrogen additions at the Harvard Forest LTER, Massachusetts, USA. For. Ecol. Manag. 2004, 196, 7-28. [CrossRef]

88. Aber, J.D.; McDowell, W.H.; Nadelhoffer, K.J.; Magill, A.H.; Berntson, G.; McNulty, S.G.; Currie, W.; Rustad, L.; Fernandez, I.J. Nitrogen saturation in temperate forest ecosystems-Hypotheses revisited. Bioscience 1998, 48, 921-934. [CrossRef] 
89. Gilliam, F.S.; Burns, D.A.; Driscoll, C.T.; Frey, S.D.; Lovett, G.M.; Watmough, S.A. Decreased atmospheric nitrogen deposition in eastern North America: Predicted responses of forest ecosystems. Environ. Pollut. 2019, 244, 560-574. [CrossRef] [PubMed]

90. Sardans, J.; Peñuelas, J. Increasing drought decreases phosphorus availability in an evergreen Mediterranean forest. Plant Soil 2004, 267, 367-377. [CrossRef]

91. Braun, S.; Thomas, V.F.D.; Quiring, R.; Flückiger, W. Does nitrogen deposition increase forest production? The role of phosphorus. Environ. Pollut. 2010, 158, 2043-2052. [CrossRef] [PubMed]

92. Jonard, M.; Fürst, A.; Verstraeten, A.; Thimonier, A.; Timmermann, V.; Potočić, N.; Waldner, P.; Benham, S.; Hansen, K.; Merilä, P.; et al. Tree mineral nutrition is deteriorating in Europe. Glob. Chang. Biol. 2015, 21, 418-430. [CrossRef]

93. Talkner, U.; Meiwes, K.J.; Potočić, N.; Seletković, I.; Cools, N.; De Vos, B.; Rautio, P. Phosphorus nutrition of beech (Fagus sylvatica L.) is decreasing in Europe. Ann. For. Sci. 2015, 72, 919-928. [CrossRef]

94. Nilsson, L.O.; Wallander, H. Production of external mycelium by ectomycorrhizal fungi in a norway spruce forest was reduced in response to nitrogen fertilization. New Phytol. 2003, 158, 409-416. [CrossRef]

95. Huang, Z.; Liu, B.; Davis, M.; Sardans, J.; Peñuelas, J.; Billings, S. Long-term nitrogen deposition linked to reduced water use efficiency in forests with low phosphorus availability. New Phytol. 2016, 210, 431-442. [CrossRef] [PubMed]

96. Rossi, S.; Deslauriers, A.; Griçar, J.; Seo, J.W.; Rathgeber, C.B.K.; Anfodillo, T.; Morin, H.; Levanic, T.; Oven, P.; Jalkanen, R. Critical temperatures for xylogenesis in conifers of cold climates. Glob. Ecol. Biogeogr. 2008, 17, 696-707. [CrossRef]

97. Poulter, B.; Pederson, N.; Liu, H.; Zhu, Z.; D’Arrigo, R.; Ciais, P.; Davi, N.; Frank, D.; Leland, C.; Myneni, R.; et al. Recent trends in Inner Asian forest dynamics to temperature and precipitation indicate high sensitivity to climate change. Agric. For. Meteorol. 2013, 178, 31-45. [CrossRef]

98. Waterhouse, J.S.; Switsur, V.R.; Barker, A.C.; Carter, A.H.C.; Hemming, D.L.; Loader, N.J.; Robertson, I. Northern European trees show a progressively diminishing response to increasing atmospheric carbon dioxide concentrations. Quat. Sci. Rev. 2004, 23, 803-810. [CrossRef]

99. Lévesque, M.; Siegwolf, R.; Saurer, M.; Eilmann, B.; Rigling, A. Increased water-use efficiency does not lead to enhanced tree growth under xeric and mesic conditions. New Phytol. 2014, 203, 94-109. [CrossRef]

100. Lindner, M.; Fitzgerald, J.B.; Zimmermann, N.E.; Reyer, C.; Delzon, S.; van der Maaten, E.; Schelhaas, M.J.; Lasch, P.; Eggers, J.; van der Maaten-Theunissen, M.; et al. Climate change and European forests: What do we know, what are the uncertainties, and what are the implications for forest management? J. Environ. Manag. 2014, 146, 69-83. [CrossRef]

101. Nock, C.A.; Baker, P.J.; Wanek, W.; Leis, A.; Grabner, M.; Bunyavejchewin, S.; Hietz, P. Long-term increases in intrinsic water-use efficiency do not lead to increased stem growth in a tropical monsoon forest in western Thailand. Glob. Chang. Biol. 2011, 17, 1049-1063. [CrossRef]

102. González de Andrés, E.; Camarero, J.J.; Blanco, J.A.; Imbert, J.B.; Lo, Y.H.; Sangüesa-Barreda, G.; Castillo, F.J. Tree-to-tree competition in mixed European beech-Scots pine forests has different impacts on growth and water-use efficiency depending on site conditions. J. Ecol. 2018, 106, 59-75. [CrossRef]

103. Wullschleger, S.D.; Tschaplinski, T.J.; Norby, R.J. Plant water relations at elevated $\mathrm{CO}_{2}$-Implications for water-limited environments. Plant Cell Environ. 2002, 25, 319-331. [CrossRef]

104. Lloyd, J.; Farquhar, G.D. Effects of rising temperatures and $\left[\mathrm{CO}_{2}\right]$ on the physiology of tropical forest trees. Philos. Trans. R. Soc. B Biol. Sci. 2008, 363, 1811-1817. [CrossRef]

105. McDowell, N.; Pockman, W.T.; Allen, C.D.; Breshears, D.D.; Cobb, N.; Kolb, T.; Plaut, J.; Sperry, J.; West, A.; Williams, D.G.; et al. Mechanisms of plants mortality during drought: Why do some plants survive while others succumb to drought? New Phytol. 2008, 178, 719-739. [CrossRef] [PubMed]

106. Pinheiro, C.; Chaves, M.M. Photosynthesis and drought: Can we make metabolic connections from available data? J. Exp. Bot. 2011, 62, 869-882. [CrossRef] [PubMed]

107. McDowell, N.G. Mechanisms linking drought, hydraulics, carbon metabolism, and vegetation mortality. Plant Physiol. 2011, 155, 1051-1059. [CrossRef] [PubMed]

108. Dziedek, C.; Härdtle, W.; Von Oheimb, G.; Fichtner, A. Nitrogen addition enhances drought sensitivity of young deciduous tree species. Front. Plant Sci. 2016, 7, 1100. [CrossRef] [PubMed]

109. Lévesque, M.; Walthert, L.; Weber, P. Soil nutrients influence growth response of temperate tree species to drought. J. Ecol. 2016, 104, 377-387. [CrossRef] 
110. Thornton, P.E.; Lamarque, J.F.; Rosenbloom, N.A.; Mahowald, N.M. Influence of carbon-nitrogen cycle coupling on land model response to $\mathrm{CO}_{2}$ fertilization and climate variability. Glob. Biogeochem. Cycles 2007, 21. [CrossRef]

111. Gessler, A.; Schaub, M.; McDowell, N.G. The role of nutrients in drought-induced tree mortality and recovery. New Phytol. 2017, 214, 513-520. [CrossRef]

112. Kreuzwieser, J.; Gessler, A. Global climate change and tree nutrition: Influence of water availability. Tree Physiol. 2010, 30, 1221-1234. [CrossRef]

113. van Lierop, P.; Lindquist, E.; Sathyapala, S.; Franceschini, G. Global forest area disturbance from fire, insect pests, diseases and severe weather events. For. Ecol. Manag. 2015, 352, 78-88. [CrossRef]

114. Carnicer, J.; Coll, M.; Ninyerola, M.; Pons, X.; Sanchez, G.; Penuelas, J. Widespread crown condition decline, food web disruption, and amplified tree mortality with increased climate change-type drought. Proc. Natl. Acad. Sci. USA 2011, 108, 1474-1478. [CrossRef]

115. McDowell, N.G.; Beerling, D.J.; Breshears, D.D.; Fisher, R.A.; Raffa, K.F.; Stitt, M. The interdependence of mechanisms underlying climate-driven vegetation mortality. Trends Ecol. Evol. 2011, 26, 523-532. [CrossRef] [PubMed]

116. Dieleman, W.I.J.; Vicca, S.; Dijkstra, F.A.; Hagedorn, F.; Hovenden, M.J.; Larsen, K.S.; Morgan, J.A.; Volder, A.; Beier, C.; Dukes, J.S.; et al. Simple additive effects are rare: A quantitative review of plant biomass and soil process responses to combined manipulations of $\mathrm{CO}_{2}$ and temperature. Glob. Chang. Biol. 2012, 18, 2681-2693. [CrossRef] [PubMed]

117. Zavaleta, E.S.; Shaw, M.R.; Chiariello, N.R.; Mooney, H.A.; Field, C.B. Additive effects of simulated climate changes, elevated $\mathrm{CO}_{2}$, and nitrogen deposition on grassland diversity. Proc. Natl. Acad. Sci. USA 2003, 100, 7650-7654. [CrossRef] [PubMed]

118. González de Andrés, E.; Blanco, J.A.; Imbert, J.B.; Guan, B.T.; Lo, Y.; Castillo, F.J. ENSO and NAO affect long-term leaf litter dynamics and stoichiometry of Scots pine and European beech mixedwoods. Glob. Chang. Biol. 2019. [CrossRef]

119. Coomes, D.A.; Flores, O.; Holdaway, R.; Jucker, T.; Lines, E.R.; Vanderwel, M.C. Wood production response to climate change will depend critically on forest composition and structure. Glob. Chang. Biol. 2014, 20, 3632-3645. [CrossRef]

120. Grossiord, C.; Granier, A.; Ratcliffe, S.; Bouriaud, O.; Bruelheide, H.; Checko, E.; Forrester, D.I.; Dawud, S.M.; Finer, L.; Pollastrini, M.; et al. Tree diversity does not always improve resistance of forest ecosystems to drought. Proc. Natl. Acad. Sci. USA 2014, 111, 14812-14815. [CrossRef] [PubMed]

121. Linares, J.C.; Delgado-Huertas, A.; Camarero, J.J.; Merino, J.; Carreira, J.A. Competition and drought limit the response of water-use efficiency to rising atmospheric carbon dioxide in the Mediterranean fir Abies pinsapo. Oecologia 2009, 161, 611-624. [CrossRef]

122. Primicia, I.; Camarero, J.J.; Imbert, J.B.; Castillo, F.J. Effects of thinning and canopy type on growth dynamics of Pinus sylvestris: Inter-annual variations and intra-annual interactions with microclimate. Eur. J. For. Res. 2013, 132, 121-135. [CrossRef]

123. Fernández-de-Uña, L.; Mcdowell, N.G.; Cañellas, I.; Gea-Izquierdo, G. Disentangling the effect of competition, $\mathrm{CO}_{2}$ and climate on intrinsic water-use efficiency and tree growth. J. Ecol. 2016, 104, 678-690. [CrossRef]

124. Metz, J.; Annighöfer, P.; Schall, P.; Zimmermann, J.; Kahl, T.; Schulze, E.D.; Ammer, C. Site-adapted admixed tree species reduce drought susceptibility of mature European beech. Glob. Chang. Biol. 2016, 22, 903-920. [CrossRef]

125. Bertness, M.D.; Callaway, R. Positive interactions in communities. Trends Ecol. Evol. 1994, 9, $191-193$. [CrossRef]

126. Hooper, D.U. The role of complementarity and competition in ecosystem responses to variation in plant diversity. Ecology 1998, 79, 704-719. [CrossRef]

127. Loreau, M.; Hector, A. Partitioning selection and complementarity in biodiversity experiments. Nature 2001, 412, 72-76. [CrossRef] [PubMed]

128. Forrester, D.I.; Bauhus, J. A review of processes behind diversity-productivity relationships in forests. Curr. For. Rep. 2016, 2, 45-61. [CrossRef]

129. Ammer, C. Diversity and forest productivity in a changing climate. New Phytol. 2019, 221, 50-66. [CrossRef] [PubMed] 
130. Loreau, M. Biodiversity and ecosystem functioning: Recent theoretical advances. Oikos 2000, 91, 3-17. [CrossRef]

131. Tobner, C.M.; Paquette, A.; Gravel, D.; Reich, P.B.; Williams, L.J.; Messier, C. Functional identity is the main driver of diversity effects in young tree communities. Ecol. Lett. 2016, 19, 638-647. [CrossRef]

132. Mori, A.S. Environmental controls on the causes and functional consequences of tree species diversity. J. Ecol. 2018, 106, 113-125. [CrossRef]

133. Grossman, J.J.; Cavender-Bares, J.; Hobbie, S.E.; Reich, P.B.; Montgomery, R.A. Species richness and traits predict overyielding in stem growth in an early-successional tree diversity experiment. Ecology 2017, 98, 2601-2614. [CrossRef]

134. Niklaus, P.A.; Baruffol, M.; He, J.S.; Ma, K.; Schmid, B. Can niche plasticity promote biodiversity-productivity relationships through increased complementarity? Ecology 2017, 98, 1104-1116. [CrossRef]

135. Lebourgeois, F.; Gomez, N.; Pinto, P.; Mérian, P. Mixed stands reduce Abies alba tree-ring sensitivity to summer drought in the Vosges mountains, western Europe. For. Ecol. Manag. 2013, 303, 61-71. [CrossRef]

136. Pretzsch, H.; Schütze, G.; Uhl, E. Resistance of European tree species to drought stress in mixed versus pure forests: Evidence of stress release by inter-specific facilitation. Plant Biol. 2013, 15, 483-495. [CrossRef] [PubMed]

137. Mölder, I.; Leuschner, C. European beech grows better and is less drought sensitive in mixed than in pure stands: Tree neighbourhood effects on radial increment. Trees-Struct. Funct. 2014, 28, 777-792. [CrossRef]

138. Kunert, N.; Mercado Cárdenas, A. Are mixed tropical tree plantations more resistant to drought than monocultures? Forests 2015, 6, 2029-2046. [CrossRef]

139. Grossiord, C.; Granier, A.; Gessler, A.; Jucker, T.; Bonal, D. Does drought influence the relationship between biodiversity and ecosystem functioning in boreal forests? Ecosystems 2014, 17, 394-404. [CrossRef]

140. Merlin, M.; Perot, T.; Perret, S.; Korboulewsky, N.; Vallet, P. Effects of stand composition and tree size on resistance and resilience to drought in sessile oak and Scots pine. For. Ecol. Manag. 2015, 339, $22-33$. [CrossRef]

141. Grossiord, C. Having the right neighbors: How tree species diversity modulates drought impacts on forests. New Phytol. 2018. [CrossRef]

142. Forrester, D.I. The spatial and temporal dynamics of species interactions in mixed-species forests: From pattern to process. For. Ecol. Manag. 2014, 312, 282-292. [CrossRef]

143. Forrester, D.I.; Bonal, D.; Dawud, S.; Gessler, A.; Granier, A.; Pollastrini, M.; Grossiord, C. Drought responses by individual tree species are not often correlated with tree species diversity in European forests. J. Appl. Ecol. 2016, 53, 1725-1734. [CrossRef]

144. Jucker, T.; Avăcăritei, D.; Bărnoaiea, I.; Duduman, G.; Bouriaud, O.; Coomes, D.A. Climate modulates the effects of tree diversity on forest productivity. J. Ecol. 2016, 104, 388-398. [CrossRef]

145. Ratcliffe, S.; Wirth, C.; Jucker, T.; van der Plas, F.; Scherer-Lorenzen, M.; Verheyen, K.; Allan, E.; Benavides, R.; Bruelheide, H.; Ohse, B.; et al. Biodiversity and ecosystem functioning relations in European forests depend on environmental context. Ecol. Lett. 2017, 20, 1414-1426. [CrossRef] [PubMed]

146. Jactel, H.; Gritti, E.S.; Drössler, L.; Forrester, D.I.; Mason, W.L.; Morin, X.; Pretzsch, H.; Castagneyrol, B. Positive biodiversity-productivity relationships in forests: Climate matters. Biol. Lett. 2018, 14, 12-15. [CrossRef] [PubMed]

147. Mina, M.; Huber, M.O.; Forrester, D.I.; Thürig, E.; Rohner, B. Multiple factors modulate tree growth complementarity in Central European mixed forests. J. Ecol. 2018, 106, 1106-1119. [CrossRef]

148. Paquette, A.; Vayreda, J.; Coll, L.; Messier, C.; Retana, J. Climate change could negate positive tree diversity effects on forest productivity: A study across five climate types in Spain and Canada. Ecosystems 2018, 21, 960-970. [CrossRef]

149. Maestre, F.T.; Callaway, R.M.; Valladares, F.; Lortie, C.J. Refining the stress-gradient hypothesis for competition and facilitation in plant communities. J. Ecol. 2009, 97, 199-205. [CrossRef]

150. Condés, S.; Del Rio, M.; Sterba, H. Mixing effect on volume growth of Fagus sylvatica and Pinus sylvestris is modulated by stand density. For. Ecol. Manag. 2013, 292, 86-95. [CrossRef]

151. Pretzsch, H.; del Río, M.; Schütze, G.; Ammer, C.; Annighöfer, P.; Avdagic, A.; Barbeito, I.; Bielak, K.; Brazaitis, G.; Coll, L.; et al. Mixing of Scots pine (Pinus sylvestris L.) and European beech (Fagus sylvatica L.) enhances structural heterogeneity, and the effect increases with water availability. For. Ecol. Manag. 2016, 373, 149-166. [CrossRef] 
152. Lübbe, T.; Schuldt, B.; Leuschner, C. Species identity and neighbor size surpass the impact of tree species diversity on productivity in experimental broad-leaved tree sapling assemblages under dry and moist conditions. Front. Plant Sci. 2015, 6, 857. [CrossRef]

153. Vitali, V.; Forrester, D.I.; Bauhus, J. Know your neighbours: Drought response of Norway spruce, silver fir and Douglas fir in mixed forests depends on species identity and diversity of tree neighbourhoods. Ecosystems 2018, 21, 1215-1229. [CrossRef]

154. Yuan, Z.; Wang, S.; Ruiz-Benito, P.; Wang, X.; Gazol, A.; Ye, J.; Lin, F.; Hao, Z.; Ali, A.; Yuan, Z.; et al. Aboveground carbon storage is driven by functional trait composition and stand structural attributes rather than biodiversity in temperate mixed forests recovering from disturbances. Ann. For. Sci. 2018, 75, 67. [CrossRef]

155. Aranda, I.; Forner, A.; Cuesta, B.; Valladares, F. Species-specific water use by forest tree species: From the tree to the stand. Agric. Water Manag. 2012, 114, 67-77. [CrossRef]

156. Reich, P.B.; Knops, J.; Tilman, D.; Craine, J.; Ellsworth, D.; Tjoelker, M.; Lee, T.; Wedin, D.; Naeem, S.; Bahauddin, D.; et al. Plant diversity enhances ecosystem responses to elevated $\mathrm{CO}_{2}$ and nitrogen deposition. Nature 2001, 410, 809. [CrossRef] [PubMed]

157. Yuan, Z.Y.; Chen, H.Y.H. Decoupling of nitrogen and phosphorus in terrestrial plants associated with global changes. Nat. Clim. Chang. 2015, 5, 465-469. [CrossRef]

158. Schmidt, M.; Veldkamp, E.; Corre, M.D. Tree species diversity effects on productivity, soil nutrient availability and nutrient response efficiency in a temperate deciduous forest. For. Ecol. Manag. 2015, 338, 114-123. [CrossRef]

159. Sterner, R.W.; Elser, J.J. Ecological Stoichiometry: The Biology of Elements from Molecules to the Biosphere; Princeton University Press: Princeton, NJ, USA, 2002.

160. Finzi, A.C.; Austin, A.T.; Cleland, E.E.; Frey, S.D.; Houlton, B.Z.; Wallenstein, M.D. Responses and feedbacks of coupled biogeochemical cycles to climate change: Examples from terrestrial ecosystems. Front. Ecol. Environ. 2011, 9, 61-67. [CrossRef]

161. Güsewell, S.; Bailey, K.M.; Roem, W.J.; Bedford, B.L. Nutrient limitation and botanical diversity in wetlands: Can fertilisation raise species richness? Oikos 2005, 109, 71-80. [CrossRef]

162. Sardans, J.; Rivas-Ubach, A.; Estiarte, M.; Ogaya, R.; Peñuelas, J. Field-simulated droughts affect elemental leaf stoichiometry in Mediterranean forests and shrublands. Acta Oecol. 2013, 50, 20-31. [CrossRef]

163. Berg, B.; McClaugherty, C. Plant Litter: Decomposition, Humus Formation, Carbon Sequestration; Springer: Berlin/Heidelberg, Germany, 2003.

164. Güsewell, S.; Gessner, M.O. N:P ratios influence litter decomposition and colonization by fungi and bacteria in microcosms. Funct. Ecol. 2009, 23, 211-219. [CrossRef]

165. Mooshammer, M.; Wanek, W.; Zechmeister-Boltenstern, S.; Richter, A. Stoichiometric imbalances between terrestrial decomposer communities and their resources: Mechanisms and implications of microbial adaptations to their resources. Front. Microbiol. 2014, 5, 22. [CrossRef]

166. Delgado-Baquerizo, M.; Reich, P.B.; Khachane, A.N.; Campbell, C.D.; Thomas, N.; Freitag, T.E.; Abu Al-Soud, W.; Sørensen, S.; Bardgett, R.D.; Singh, B.K. It is elemental: Soil nutrient stoichiometry drives bacterial diversity. Environ. Microbiol. 2017, 19, 1176-1188. [CrossRef]

167. González, J.R.; Trasobares, A.; Palahí, M.; Pukkala, T. Predicting stand damage and tree survival in burned forests in Catalonia (North-East Spain). Ann. For. Sci. 2007, 64, 733-742. [CrossRef]

168. Prescott, C.E. The influence of the forest canopy on nutrient cycling. Tree Physiol. 2002, 22, 1193-1200. [CrossRef] [PubMed]

169. Berg, B.; Meentemeyer, V. Litter fall in some European coniferous forests as dependent on climate: A synthesis. Can. J. For. Res. 2001, 31, 292-301. [CrossRef]

170. Blanco, J.A.; Imbert, J.B.; Castillo, F.J. Influence of site characteristics and thinning intensity on litterfall production in two Pinus sylvestris L. forests in the western Pyrenees. For. Ecol. Manag. 2006, 237, 342-352. [CrossRef]

171. Martínez-Alonso, C.; Valladares, F.; Camarero, J.J.; López Arias, M.; Serrano, M.; Rodríguez, J.A. The uncoupling of secondary growth, cone and litter production by intradecadal climatic variability in a mediterranean scots pine forest. For. Ecol. Manag. 2007, 253, 19-29. [CrossRef] 
172. Lehtonen, A.; Lindholm, M.; Hokkanen, T.; Salminen, H.; Jalkanen, R. Testing dependence between growth and needle litterfall in Scots pine-A case study in northern Finland. Tree Physiol. 2008, 28, 1741-1749. [CrossRef] [PubMed]

173. Portillo-Estrada, M.; Korhonen, J.F.J.; Pihlatie, M.; Pumpanen, J.; Frumau, A.K.F.; Morillas, L.; Tosens, T.; Niinemets, Ü. Inter- and intra-annual variations in canopy fine litterfall and carbon and nitrogen inputs to the forest floor in two European coniferous forests. Ann. For. Sci. 2013, 70, 367-379. [CrossRef]

174. Reich, P.B.; Borchert, R. Water stress and tree phenology in a tropical dry forest in the lowlands of Costa Rica. J. Ecol. 1984, 72, 61-74. [CrossRef]

175. Wright, S.J.; Cornejo, F.H. Seasonal drought and leaf fall in a tropical forest. Ecology 1990, 71, 1165-1175. [CrossRef]

176. Zhang, H.; Yuan, W.; Dong, W.; Liu, S. Seasonal patterns of litterfall in forest ecosystem worldwide. Ecol. Complex. 2014, 20, 240-247. [CrossRef]

177. Aerts, R. Climate, leaf litter chemistry and leaf litter decomposition in terrestrial ecosystems: A triangular relationship. Oikos 1997, 79, 439-449. [CrossRef]

178. McGroddy, M.E.; Daufresne, T.; Hedin, L.O. Scaling of C: N: P stoichiometry in forest ecosystems worldwide. Ecology 2004, 85, 2390-2401. [CrossRef]

179. Yuan, Z.Y.; Chen, H.Y.H. Global trends in senesced-leaf nitrogen and phosphorus. Glob. Ecol. Biogeogr. 2009, 18, 532-542. [CrossRef]

180. Kang, H.; Xin, Z.; Berg, B.; Burgess, P.J.; Liu, Q.; Liu, Z.; Li, Z.; Liu, C. Global pattern of leaf litter nitrogen and phosphorus in woody plants. Ann. For. Sci. 2010, 67, 811. [CrossRef]

181. Aerts, R.; Chapin, F.S., III. The mineral nutrition of wild plants revisited: A re-evaluation of processes and patterns. Adv. Ecol. Res. 2000, 30,1-67.

182. Reich, P.B.; Oleksyn, J. Global patterns of plant leaf $\mathrm{N}$ and $\mathrm{P}$ in relation to temperature and latitude. Proc. Natl. Acad. Sci. USA 2004, 101, 11001-11006. [CrossRef]

183. Sardans, J.; Rivas-Ubach, A.; Peñuelas, J. The elemental stoichiometry of aquatic and terrestrial ecosystems and its relationships with organismic lifestyle and ecosystem structure and function: A review and perspectives. Biogeochemistry 2012, 111, 1-39. [CrossRef]

184. Parton, W.; Silver, W.L.; Burke, I.C.; Grassens, L.; Harmon, M.E.; Currie, W.S.; King, J.Y.; Adair, E.C.; Brandt, L.A.; Hart, S.C.; et al. Global-scale similarities in nitrogen release patterns during long-term decomposition. Science 2007, 315, 361-364. [CrossRef]

185. Cornwell, W.K.; Cornelissen, J.H.C.; Amatangelo, K.; Dorrepaal, E.; Eviner, V.T.; Godoy, O.; Hobbie, S.E.; Hoorens, B.; Kurokawa, H.; Pérez-Harguindeguy, N.; et al. Plant species traits are the predominant control on litter decomposition rates within biomes worldwide. Ecol. Lett. 2008, 11, 1065-1071. [CrossRef]

186. Zhang, D.; Hui, D.; Luo, Y.; Zhou, G. Rates of litter decomposition in terrestrial ecosystems: Global patterns and controlling factors. J. Plant Ecol. 2008, 1, 85-93. [CrossRef]

187. Killingbeck, K.T. Nutrients in senesced leaves: Keys to the search for potential resorption and resorption proficiency. Ecology 1996, 77, 1716-1727. [CrossRef]

188. Kobe, R.K.; Lepczyk, C.A.; Iyer, M. Resorption efficiency decreases with increasing green leaf nutrients in a global data set. Ecology 2005, 86, 2780-2792. [CrossRef]

189. Sardans, J.; Rivas-Ubach, A.; Peñuelas, J. The C:N:P stoichiometry of organisms and ecosystems in a changing world: A review and perspectives. Perspect. Plant Ecol. Evol. Syst. 2012, 14, 33-47. [CrossRef]

190. Yang, X.; Thornton, P.E.; Ricciuto, D.M.; Post, W.M. The role of phosphorus dynamics in tropical forests-A modeling study using CLM-CNP. Biogeosciences 2014, 11, 1667-1681. [CrossRef]

191. Jacobson, T.K.B.; da Cunha Bustamante, M.M.; Kozovits, A.R. Diversity of shrub tree layer, leaf litter decomposition and $\mathrm{N}$ release in a Brazilian Cerrado under N, P and N plus P additions. Environ. Pollut. 2011, 159, 2236-2242. [CrossRef]

192. Zechmeister-Boltenstern, S.; Keiblinger, K.M.; Mooshammer, M.; Peñuelas, J.; Richter, A.; Sardans, J.; Wanek, W. The application of ecological stoichiometry to plant-microbial-soil organic matter transformations. Ecol. Monogr. 2015, 85, 133-155. [CrossRef]

193. Yuan, Z.Y.; Chen, H.Y.H. Global-scale patterns of nutrient resorption associated with latitude, temperature and precipitation. Glob. Ecol. Biogeogr. 2009, 18, 11-18. [CrossRef]

194. Güsewell, S.; Freeman, C. Nutrient limitation and enzyme activities during litter decomposition of nine wetland species in relation to litter N:P ratios. Funct. Ecol. 2005, 19, 582-593. 
195. Mooshammer, M.; Wanek, W.; Schnecker, J.; Wild, B.; Leitner, S.; Hofhansl, F.; Blochl, A.; Hammerle, I.; Frank, A.H.; Fuchslueger, L.; et al. Stoichiometric controls of nitrogen and phosphorus cycling in decomposing beech leaf litter. Ecology 2012, 93, 770-782. [CrossRef]

196. Schneider, T.; Keiblinger, K.M.; Schmid, E.; Sterflinger-Gleixner, K.; Ellersdorfer, G.; Roschitzki, B.; Richter, A.; Eberl, L.; Zechmeister-Boltenstern, S.; Riedel, K. Who is who in litter decomposition? Metaproteomics reveals major microbial players and their biogeochemical functions. ISME J. 2012, 6, 1749. [CrossRef]

197. Saura-Mas, S.; Estiarte, M.; Peñuelas, J.; Lloret, F. Effects of climate change on leaf litter decomposition across post-fire plant regenerative groups. Environ. Exp. Bot. 2012, 77, 274-282. [CrossRef]

198. Garten, C.T.; Classen, A.T.; Norby, R.J. Soil moisture surpasses elevated $\mathrm{CO}_{2}$ and temperature as a control on soil carbon dynamics in a multi-factor climate change experiment. Plant Soil 2009, 319, 85-94. [CrossRef]

199. Melillo, J.M.; Butler, S.; Johnson, J.; Mohan, J.; Steudler, P.; Lux, H.; Burrows, E.; Bowles, F.; Smith, R.; Scott, L.; et al. Soil warming, carbon-nitrogen interactions, and forest carbon budgets. Proc. Natl. Acad. Sci. USA 2011, 108, 9508-9512. [CrossRef]

200. Dijkstra, F.A.; Pendall, E.; Morgan, J.A.; Blumenthal, D.M.; Carrillo, Y.; LeCain, D.R.; Follett, R.F.; Williams, D.G. Climate change alters stoichiometry of phosphorus and nitrogen in a semiarid grassland. New Phytol. 2012, 196, 807-815. [CrossRef]

201. Knorr, M.; Frey, S.D.; Curtis, P.S. Nitrogen additions and litter decomposition: A meta-analysis. Ecology 2005, 86, 3252-3257. [CrossRef]

202. Gundersen, P.; Schmidt, I.K.; Raulund-Rasmussen, K. Leaching of nitrate from temperate forests-Effects of air pollution and forest management. Environ. Rev. 2006, 14, 1-57. [CrossRef]

203. Puettmann, K.J.; Wilson, S.M.; Baker, S.C.; Donoso, P.J.; Drössler, L.; Amente, G.; Harvey, B.D.; Knoke, T.; $\mathrm{Lu}$, Y.; Nocentini, S.; et al. Silvicultural alternatives to conventional even-aged forest management—What limits global adoption? For. Ecosyst. 2015, 2, 8. [CrossRef]

204. Puettmann, K.J. Silvicultural challenges and options in the context of global change: "Simple" fixes and opportunities for new management approaches. J. For. 2011, 109, 321-331.

205. Kimmins, J.P.; Blanco, J.A.; Seely, B.; Welham, C.; Scoullar, K. Forecasting Forest Futures: A Hybrid Modelling Approach to the Assessment of Sustainability of Forest Ecosystems and Their Values; Earthscan Ltd.: London, UK, 2010.

206. McDonald, G.T.; Lane, M.B. Converging global indicators for sustainable forest management. For. Policy Econ. 2004, 6, 63-70. [CrossRef]

207. Messier, C.; Puettmann, K.J. Forests as complex adaptive systems: Implications for forest management and modelling. Ital. J. For. Mt. Environ. 2011, 66, 249-258. [CrossRef]

208. Puettmann, J.K.; Coates, K.D.; Messier, C.C. A Critique of Silviculture-Managing for Complexity; Island Press: Washington, DC, USA, 2009.

209. Messier, C.; Puettmann, K.J.; Coates, K.D. Managing Forests as Complex Adaptive Systems: Building Resilience to the Challenge of Global Change; Routledge Chapman \& Hall: New York, NY, USA, 2013.

210. Filotas, E.; Parrott, L.; Burton, P.J.; Chazdon, R.L.; Coates, K.D.; Coll, L.; Haeussler, S.; Martin, K.; Nocentini, S.; Puettmann, K.J.; et al. Viewing forests through the lens of complex systems science. Ecosphere 2014, 5, 1-23. [CrossRef]

211. Wagner, S.; Nocentini, S.; Huth, F.; Hoogstra-Klein, M. Forest management approaches for coping with the uncertainty of climate change: Trade-offs in service provisioning and adaptability. Ecol. Soc. 2014, 19, 32. [CrossRef]

212. Bolte, A.; Ammer, C.; Löf, M.; Madsen, P.; Nabuurs, G.-J.; Schall, P.; Spathelf, P.; Rock, J. Adaptive forest management in central Europe: Climate change impacts, strategies and integrative concept. Scand. J. For. Res. 2009, 24, 473-482. [CrossRef]

213. Kolström, M.; Lindner, M.; Vilén, T.; Maroschek, M.; Seidl, R.; Lexer, M.J.; Netherer, S.; Kremer, A.; Delzon, S.; Barbati, A.; et al. Reviewing the science and implementation of climate change adaptation measures in European forestry. Forests 2011, 2, 961-982. [CrossRef]

214. Nocentini, S.; Buttoud, G.; Ciancio, O.; Corona, P. Managing forests in a changing world: The need for a systemic approach. A review. For. Syst. 2017, 26, eR01. [CrossRef]

215. O’Hara, K.L. What is close-to-nature silviculture in a changing world? Forestry 2016, 89, 1-6. [CrossRef] 
216. Bauhus, J.; Forrester, D.I.; Gardiner, B.; Jactel, H.; Vallejo, R.; Pretzsch, H. Ecological Stability of Mixed-Species Forests. In Mixed-Species Forests. Ecology and Management; Pretzsch, H., Forrester, D.I., Bauhus, J., Eds.; Springer Nature: Berlin, Germany, 2017; pp. 337-382.

217. Köhler, M.; Sohn, J.; Nägele, G.; Bauhus, J. Can drought tolerance of Norway spruce (Picea abies (L.) Karst.) be increased through thinning? Eur. J. For. Res. 2010, 129, 1109-1118. [CrossRef]

218. Sohn, J.A.; Saha, S.; Bauhus, J. Potential of forest thinning to mitigate drought stress: A meta-analysis. For. Ecol. Manag. 2016, 380, 261-273. [CrossRef]

219. Cardil, A.; Imbert, J.B.; Camarero, J.J.; Primicia, I.; Castillo, F. Temporal interactions among throughfall, type of canopy and thinning drive radial growth in an Iberian mixed pine-beech forest. Agric. For. Meteorol. 2018, 252, 62-74. [CrossRef]

220. Jactel, H.; Nicoll, B.C.; Branco, M.; Gonzalez-Olabarria, J.R.; Grodzki, W.; Långström, B.; Moreira, F.; Netherer, S.; Orazio, C.; Piou, D.; et al. The influences of forest stand management on biotic and abiotic risks of damage. Ann. For. Sci. 2009, 66, 701. [CrossRef]

221. Neuner, S.; Albrecht, A.; Cullmann, D.; Engels, F.; Griess, V.C.; Hahn, W.A.; Hanewinkel, M.; Härtl, F.; Kölling, C.; Staupendahl, K.; et al. Survival of Norway spruce remains higher in mixed stands under a dryer and warmer climate. Glob. Chang. Biol. 2015, 21, 935-946. [CrossRef]

222. Cardinale, B.J.; Duffy, J.E.; Gonzalez, A.; Hooper, D.U.; Perrings, C.; Venail, P.; Narwani, A.; Mace, G.M.; Tilman, D.; Wardle, D.A.; et al. Biodiversity loss and its impact on humanity. Nature 2012, 486, 59. [CrossRef]

223. Gamfeldt, L.; Snäll, T.; Bagchi, R.; Jonsson, M.; Gustafsson, L.; Kjellander, P.; Ruiz-Jaen, M.C.; Fröberg, M.; Stendahl, J.; Philipson, C.D.; et al. Higher levels of multiple ecosystem services are found in forests with more tree species. Nat. Commun. 2013, 4, 1340. [CrossRef]

224. Paquette, A.; Messier, C. The effect of biodiversity on tree productivity: From temperate to boreal forests. Glob. Ecol. Biogeogr. 2011, 20, 170-180. [CrossRef]

225. Barrufol, M.; Schmid, B.; Bruelheide, H.; Chi, X.; Hector, A.; Ma, K.; Michalski, S.; Tang, Z.; Niklaus, P.A. Biodiversity promotes tree growth during succession in subtropical forest. PLoS ONE 2013, 8, e81246. [CrossRef]

226. Vilà, M.; Carrillo-Gavilán, A.; Vayreda, J.; Bugmann, H.; Fridman, J.; Grodzki, W.; Haase, J.; Kunstler, G.; Schelhaas, M.J.; Trasobares, A. Disentangling biodiversity and climatic determinants of wood production. PLoS ONE 2013, 8, e53530. [CrossRef]

227. Jucker, T.; Bouriaud, O.; Avacaritei, D.; Dănilă, I.; Duduman, G.; Valladares, F.; Coomes, D.A. Competition for light and water play contrasting roles in driving diversity-productivity relationships in Iberian forests. J. Ecol. 2014, 102, 1202-1213. [CrossRef]

228. Pretzsch, H.; del Río, M.; Ammer, C.; Avdagic, A.; Barbeito, I.; Bielak, K.; Brazaitis, G.; Coll, L.; Dirnberger, G.; Drössler, L.; et al. Growth and yield of mixed versus pure stands of Scots pine (Pinus sylvestris L.) and European beech (Fagus sylvatica L.) analysed along a productivity gradient through Europe. Eur. J. For. Res. 2015, 134, 927-947. [CrossRef]

229. Fichtner, A.; Härdtle, W.; Bruelheide, H.; Kunz, M.; Li, Y.; Von Oheimb, G. Neighbourhood interactions drive overyielding in mixed-species tree communities. Nat. Commun. 2018, 9, 1144. [CrossRef]

230. Zhang, Y.; Chen, H.Y.H.; Reich, P.B. Forest productivity increases with evenness, species richness and trait variation: A global meta-analysis. J. Ecol. 2012, 100, 742-749. [CrossRef]

231. Liang, J.; Crowther, T.W.; Picard, N.; Wiser, S.; Zhou, M.; Alberti, G.; Schulze, E.D.; McGuire, A.D.; Bozzato, F.; Pretzsch, H.; et al. Positive biodiversity-productivity relationship predominant in global forests. Science 2016, 354. [CrossRef]

232. Gómez-Aparicio, L.; García-Valdés, R.; Ruíz-Benito, P.; Zavala, M.A. Disentangling the relative importance of climate, size and competition on tree growth in Iberian forests: Implications for forest management under global change. Glob. Chang. Biol. 2011, 17, 2400-2414. [CrossRef]

233. Madrigal-González, J.; Ruiz-Benito, P.; Ratcliffe, S.; Calatayud, J.; Kändler, G.; Lehtonen, A.; Dahlgren, J.; Wirth, C.; Zavala, M.A. Complementarity effects on tree growth are contingent on tree size and climatic conditions across Europe. Sci. Rep. 2016, 6, 32233. [CrossRef]

234. Dzikiti, S.; Gush, M.B.; Le Maitre, D.C.; Maherry, A.; Jovanovic, N.Z.; Ramoelo, A.; Cho, M.A. Quantifying potential water savings from clearing invasive alien Eucalyptus camaldulensis using in situ and high resolution remote sensing data in the Berg River Catchment, Western Cape, South Africa. For. Ecol. Manag. 2016, 361, 69-80. [CrossRef] 
235. del Río, M.; Schütze, G.; Pretzsch, H. Temporal variation of competition and facilitation in mixed species forests in Central Europe. Plant Biol. 2014, 16, 166-176. [CrossRef]

236. Cavard, X.; Macdonald, S.E.; Bergeron, Y.; Chen, H.Y.H. Importance of mixedwoods for biodiversity conservation: Evidence for understory plants, songbirds, soil fauna, and ectomycorrhizae in northern forests. Environ. Rev. 2011, 19, 142-161. [CrossRef]

237. Pretzsch, H.; Bielak, K.; Block, J.; Bruchwald, A.; Dieler, J.; Ehrhart, H.P.; Kohnle, U.; Nagel, J.; Spellmann, H.; Zasada, M.; et al. Productivity of mixed versus pure stands of oak (Quercus petraea (Matt.) Liebl. and Quercus robur L.) and European beech (Fagus sylvatica L.) along an ecological gradient. Eur. J. For. Res. 2013, 132, 263-280. [CrossRef]

238. Binkley, D.; Stape, J.L.; Ryan, M.G. Thinking about efficiency of resource use in forests. For. Ecol. Manag. 2004, 193, 5-16. [CrossRef]

239. Richards, A.E.; Forrester, D.I.; Bauhus, J.; Scherer-Lorenzen, M. The influence of mixed tree plantations on the nutrition of individual species: A review. Tree Physiol. 2010, 30, 1192-1208. [CrossRef]

240. Forrester, D.I.; Ammer, C.; Annighöfer, P.J.; Barbeito, I.; Bielak, K.; Bravo-Oviedo, A.; Coll, L.; del Río, M.; Drössler, L.; Heym, M.; et al. Effects of crown architecture and stand structure on light absorption in mixed and monospecific Fagus sylvatica and Pinus sylvestris forests along a productivity and climate gradient through Europe. J. Ecol. 2018, 106, 746-760. [CrossRef]

241. Jucker, T.; Bouriaud, O.; Coomes, D.A. Crown plasticity enables trees to optimize canopy packing in mixed-species forests. Funct. Ecol. 2015, 29, 1078-1086. [CrossRef]

242. Del Río, M.; Condés, S.; Pretzsch, H. Analyzing size-symmetric vs. size-asymmetric and intra-vs. inter-specific competition in beech (Fagus sylvatica L.) mixed stands. For. Ecol. Manag. 2014, 325, 90-98. [CrossRef]

243. González de Andrés, E.; Seely, B.; Blanco, J.A.; Imbert, J.B.; Lo, Y.H.; Castillo, F.J. Increased complementarity in water-limited environments in Scots pine and European beech mixtures under climate change. Ecohydrology 2017, 10, e1810. [CrossRef]

244. Jucker, T.; Bouriaud, O.; Avacaritei, D.; Coomes, D.A. Stabilizing effects of diversity on aboveground wood production in forest ecosystems: Linking patterns and processes. Ecol. Lett. 2014, 17, 1560-1569. [CrossRef]

245. Aussenac, R.; Bergeron, Y.; Ghotsa Mekontchou, C.; Gravel, D.; Pilch, K.; Drobyshev, I. Intraspecific variability in growth response to environmental fluctuations modulates the stabilizing effect of species diversity on forest growth. J. Ecol. 2017, 105, 1010-1020. [CrossRef]

246. del Río, M.; Pretzsch, H.; Ruíz-Peinado, R.; Ampoorter, E.; Annighöfer, P.; Barbeito, I.; Bielak, K.; Brazaitis, G.; Coll, L.; Drössler, L.; et al. Species interactions increase the temporal stability of community productivity in Pinus sylvestris-Fagus sylvatica mixtures across Europe. J. Ecol. 2017, 105, 1032-1043. [CrossRef]

247. Morin, X.; Fahse, L.; de Mazancourt, C.; Scherer-Lorenzen, M.; Bugmann, H. Temporal stability in forest productivity increases with tree diversity due to asynchrony in species dynamics. Ecol. Lett. 2014, 17, 1526-1535. [CrossRef]

248. Silva Pedro, M.; Rammer, W.; Seidl, R. Tree species diversity mitigates disturbance impacts on the forest carbon cycle. Oecologia 2015, 177, 619-630. [CrossRef]

249. Ives, A.R.; Carpenter, S.R. Stability and diversity of ecosystems. Science 2007, 317, 58-62. [CrossRef]

250. Hector, A.; Hautier, Y.; Saner, P.; Wacker, L.; Bagchi, R.; Joshi, J.; Scherer-Lorenzen, M.; Spehn, E.M.; Bazeley-White, E.; Weilenmann, M.; et al. General stabilizing effects of plant diversity on grassland productivity through population asynchrony and overyielding. Ecology 2010, 91, 2213-2220. [CrossRef]

251. Loreau, M.; de Mazancourt, C. Biodiversity and ecosystem stability: A synthesis of underlying mechanisms. Ecol. Lett. 2013, 16, 106-115. [CrossRef] [PubMed]

252. Yachi, S.; Loreau, M. Biodiversity and ecosystem productivity in a fluctuating environment: The insurance hypothesis. Proc. Natl. Acad. Sci. USA 1999, 96, 1463-1468. [CrossRef] [PubMed]

253. Forrester, D.I.; Collopy, J.J.; Morris, J.D. Transpiration along an age series of Eucalyptus globulus plantations in southeastern Australia. For. Ecol. Manag. 2010, 259, 1754-1760. [CrossRef]

254. Forrester, D.I. Transpiration and water-use efficiency in mixed-species forests versus monocultures: Effects of tree size, stand density and season. Tree Physiol. 2015, 35, 289-304. [CrossRef] [PubMed]

255. Hély, C.; Bergeron, Y.; Flannigan, M.D. Effects of stand composition on fire hazard in mixed-wood Canadian boreal forest. J. Veg. Sci. 2000, 11, 813-824. [CrossRef] 
256. Griess, V.C.; Knoke, T. Growth performance, windthrow, and insects: Meta-analyses of parameters influencing performance of mixed-species stands in boreal and northern temperate biomes. Can. J. For. Res. 2011, 41, 1141-1159. [CrossRef]

257. Jactel, H.; Brockerhoff, E.G. Tree diversity reduces herbivory by forest insects. Ecol. Lett. 2007, 10, 835-848. [CrossRef]

258. Gazol, A.; Camarero, J.J. Functional diversity enhances silver fir growth resilience to an extreme drought. J. Ecol. 2016, 104, 1063-1075. [CrossRef]

259. He, Y.; Qin, L.; Li, Z.; Liang, X.; Shao, M.; Tan, L. Carbon storage capacity of monoculture and mixed-species plantations in subtropical China. For. Ecol. Manag. 2013, 295, 193-198. [CrossRef]

260. Griess, V.C.; Knoke, T. Bioeconomic modeling of mixed Norway spruce-European beech stands: Economic consequences of considering ecological effects. Eur. J. For. Res. 2013, 132, 511-522. [CrossRef]

261. Liu, C.L.C.; Kuchma, O.; Krutovsky, K.V. Mixed-species versus monocultures in plantation forestry: Development, benefits, ecosystem services and perspectives for the future. Glob. Ecol. Conserv. 2018, 15, e00419. [CrossRef]

262. Pretzsch, H.; Dieler, J.; Seifert, T.; Rötzer, T. Climate effects on productivity and resource-use efficiency of Norway spruce (Picea abies [L.] Karst.) and European beech (Fagus sylvatica [L.]) in stands with different spatial mixing patterns. Trees-Struct. Funct. 2012, 26, 1343-1360. [CrossRef]

263. Rötzer, T. Mixing patterns of tree species and their effects on resource allocation and growth in forest stands. Nova Acta Leopold 2013, 114, 239-254.

264. Kimmins, J.P.; Blanco, J.A.; Seely, B.; Welham, C.; Scoullar, K. Complexity in modelling forest ecosystems: How much is enough? For. Ecol. Manag. 2008, 256, 1646-1658. [CrossRef]

265. Blanco, J.A.; González de Andrés, E.; San Emeterio, L.; Lo, Y.-H. Modelling mixed forest stands: Methodological challenges and approaches. In Advanced Modelling Techniques Studying Global Changes in Environmental Sciences; Lek, S., Park, Y.S., Baehr, C., Jorgensen, E.S., Eds.; Elsevier: Amsterdam, The Netherlands, 2015; pp. 189-215, ISBN 978-0-444-63536-5.

(C) 2019 by the author. Licensee MDPI, Basel, Switzerland. This article is an open access article distributed under the terms and conditions of the Creative Commons Attribution (CC BY) license (http://creativecommons.org/licenses/by/4.0/). 